
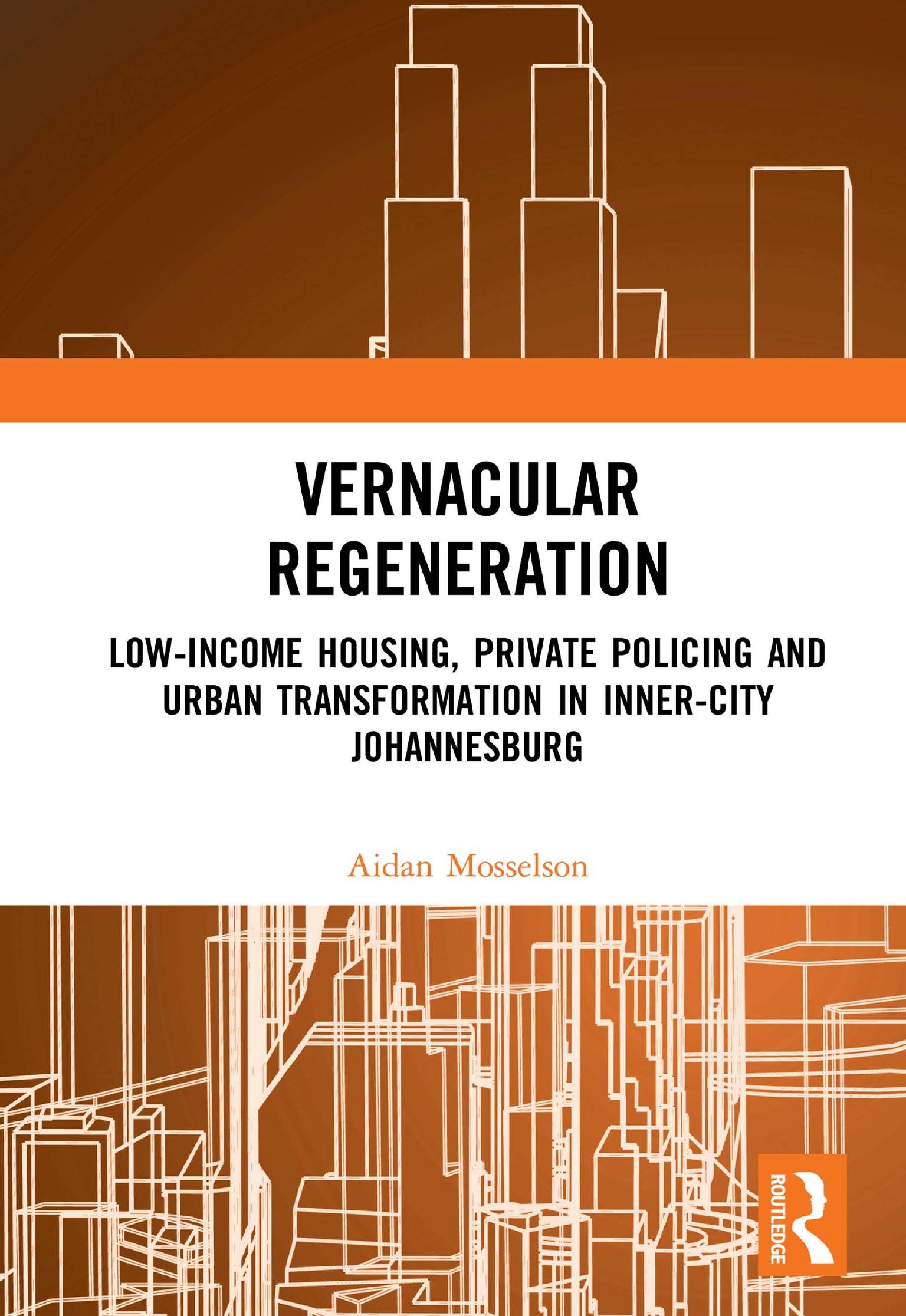


\section{Vernacular Regeneration}

Urban regeneration is currently taking place in inner-city Johannesburg. This book presents an alternative, multi-layered account for reading the process of urban change and renewal.

The provision of social and affordable housing and the spread of private security are explored through the lenses of neoliberal urbanism, gentrification, the privatisation of public space and revanchist policing. This book interrogates these concepts and challenges their assumptions based on new qualitative and ethnographic evidence emerging out of Johannesburg. Dated concepts in Critical Urban Studies are re-evaluated and the book calls for an alternative, adaptable approach, focusing on how we develop a vocabulary and creative understanding of urban regeneration.

This book is an outstanding contribution to theoretical and comparative approaches to understanding cities and processes of urban change. It offers practical insights and experiences which will be of considerable use to practitioners, policy-makers and urban planning students.

Aidan Mosselson is currently a Newton International Fellow, based at the Department of Urban Studies and Planning, University of Sheffield. He completed his PhD in Social Geography at University College London in 2015 and was Associate Lecturer in the Sociology Department at the University of the Witwatersrand, South Africa. He held a Post-Doctoral Research Fellowship at the University of Johannesburg and the Gauteng City-Region Observatory. In 2017, he was awarded an International Fellowship by the Urban Studies Foundation, which supported a stint as a Visiting Fellow at LSE Cities. 
This page intentionally left blank 


\section{Vernacular Regeneration Low-income Housing, Private Policing and Urban Transformation in Inner-city Johannesburg}

\section{Aidan Mosselson}


First published 2019

by Routledge

2 Park Square, Milton Park, Abingdon, Oxon OX14 4RN

and by Routledge

711 Third Avenue, New York, NY 10017

Routledge is an imprint of the Taylor \& Francis Group, an informa business

(C) 2019 Aidan Mosselson

The right of Aidan Mosselson to be identified as author of this work has been asserted by him in accordance with sections 77 and 78 of the Copyright, Designs and Patents Act 1988.

All rights reserved. No part of this book may be reprinted or reproduced or utilised in any form or by any electronic, mechanical, or other means, now known or hereafter invented, including photocopying and recording, or in any information storage or retrieval system, without permission in writing from the publishers.

Trademark notice: Product or corporate names may be trademarks or registered trademarks, and are used only for identification and explanation without intent to infringe.

British Library Cataloguing-in-Publication Data

A catalogue record for this book is available from the British Library

Library of Congress Cataloging-in-Publication Data

A catalog record has been requested for this book

ISBN: 978-1-138-74694-7 (hbk)

ISBN: 978-1-315-18040-3 (ebk)

Typeset in Times New Roman

by Integra Software Services Pvt. Ltd. 


\section{Contents}

List of illustrations vi vi

Acknowledgements vii

List of acronyms ix

1 Thinking with and through Johannesburg 1

2 An overburdened process: the competing agendas, imperatives and outcomes of inner-city regeneration 38

3 The contradictory praxis of regeneration $\quad 62$

4 Urban management and security: private policing, atmospheres of control and everyday practices

5 Ambiguous experiences of regeneration: spatial capital, agency and living in-between

6 The space that regeneration makes: regulation, security and everyday life

7 Conclusion: towards a vernacular theorisation of urban change 


\section{Illustrations}

\section{Figures}

1.1 Aerial image of inner-city 6

4.1 Surveillance camera in Hillbrow 93

4.2 Surveillance camera in Hillbrow 93

4.3 Bad Boyz street cleaning and maintenance $\quad 99$

4.4 Bad Boyz street cleaning and maintenance 100

4.5 Informal trading in Ekhaya 103

4.6 Informal trading in Ekhaya 104

4.7 Informal trading in Ekhaya 105

$\begin{array}{lll}4.8 & \text { Ekhaya Park } & 108\end{array}$

$\begin{array}{lll}4.9 & \text { Security in Ekhaya Park } & 108\end{array}$

4.10 Closed alleyways in Hillbrow $\quad 111$

4.11 Closed alleyways in Hillbrow 112

6.1 Entrances to social housing buildings 143

6.2 Entrance to an affordable housing building 143

7.1 The Old Synagogue 159

\section{Maps}

1.1 Map of inner-city 8

1.2 Overview map of buildings in which interviews were conducted 25

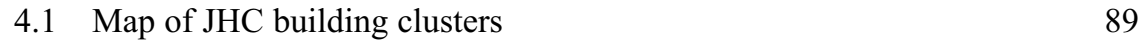

4.2 Map of Ekhaya Neighbourhood 92

\section{Table}

1.1 Buildings in which interviews were conducted 


\section{Acknowledgements}

Firstly, I would like to thank Ruth Anderson and Faye Leerink at Routledge for their assistance in bringing this book to light.

The majority of the research informing this book was conducted during the course of my $\mathrm{PhD}$, which was generously funded by the Association of Commonwealth Universities and the Oppenheimer Memorial Trust.

I am indebted to all those who participated in my research. I have done my utmost to present the accounts, stories, feelings and points of view that you shared with me honestly and accurately. I am acutely aware that this work would not have been possible without the time and access people gave me. I have endeavoured to produce work which can make a contribution, be it through informing policy and governance agendas, contributing to public debate or simply sharing and honouring certain people's stories, and thus repay some of the kindness and generosity which my research participants showed towards me.

Most of the work that went into the book was done whilst I was a PostDoctoral Research Fellow (PDRF), hosted jointly between the University of Johannesburg and the Gauteng City-Region Observatory - a partnership between the University of Johannesburg, the University of the Witwatersand and Gauteng Provincial Government. I was hugely privileged to be given the time, space and freedom to work on my own research and writing agenda, and had I not received the PDRF position this book would never have been possible. This sort of opportunity is all too rare for early-career academics, and should be made available on a far wider scale. I would like to thank Rob Moore and Graeme Gotz for giving me space to pursue my work and trusting me to manage myself and my workload. I am also grateful to Richard Ballard for his mentorship and guidance, Sian Butcher for her company and intellectual insights, Adele Underhay, Farah-Naaz Moosa, Nadine Abrahams, Elaine Milton and Ruth Mohamed for making sure everything ran smoothly and we were always well fed, and the very talented Mncedisi Siteleki for designing the maps which feature in the book. Photographs were kindly provided by Thembani Mkhize, who also played an important role in some of the later research, and whose work on Hillbrow and building managers provided valuable insights and points of learning for me. I would also like to express my appreciation to all the other members of staff at 


\section{viii Acknowledgements}

the GCRO (especially the members of the Innovation Hub!); my time there was enjoyable and I value the friendships which we made.

I was extremely fortunate to be granted an International Fellowship by the Urban Studies Foundation, which facilitated a visit to LSE Cities in the latter stages of writing. I am extremely grateful for the financial support provided by the Urban Studies Foundation and would like to thank them for the faith they placed in me and this book.

My time at LSE Cities was brief, but extremely productive. I was most fortunate to work under the guidance of Suzanne Hall, whose work, personal kindness and political convictions have long been inspirations for me. I would also like to thank Ricky Burdett and Philipp Rode for supporting my visit, Samuel Scott and Andrew Sherwood for all their support and assistance, and the team at LSE Cities for making me feel welcome.

My intellectual trajectory has been shaped by many people, but I am particularly grateful to Suzi Hall (again), Jennifer Robinson and Charlotte Lemanski who have provided me with ongoing support, mentorship and encouragement. I hope that I have merited the time and effort they have committed. I would also like to thank Claire Colomb, Claire Bénit-Gbaffou and Richard Ballard, who all played important roles in reading my work at various stages and helping me refine my thinking around particular issues.

Finally, I would like to thank my family for their constant love, support and encouragement. I would also like to thank my friends in Johannesburg and London. Above all, I have to thank Lioba Hirsch for being my source of motivation, intellectual companion, best friend and love.

An earlier version of chapters 5 and 6 appeared in "“It's not a place I like, but I can live with it": ambiguous experiences of living in state-subsidised rental housing in inner-city Johannesburg,' Transformation: Critical Perspectives on Southern Africa, 2017, 93, 142-169. Some of the information regarding urban regeneration and housing policy in chapters 1 and 2 can be found in my chapter 'Caught between the market and transformation: urban regeneration and the provision of low-income housing in inner-city Johannesburg,' in P. Watt and P. Smets (Eds.), Social Housing and Urban Renewal: A Cross-National Perspective (Emerald, 2017). Earlier parts of Chapter 7 were published in "Joburg has its own momentum": towards a vernacular theorisation of urban change,' Urban Studies, 2017, 54 (5), 1280-1296. 


\section{Acronyms}

$\begin{array}{ll}\text { AFHCO } & \text { Affordable Housing Company } \\ \text { BBP } & \text { Better Buildings Programme } \\ \text { BID } & \text { Business Improvement District } \\ \text { BNG } & \text { Breaking New Ground } \\ \text { CBD } & \text { Central Business District } \\ \text { CDS } & \text { City Development Strategy } \\ \text { CID } & \text { City Improvement District } \\ \text { CJP } & \text { Central Johannesburg Partnership } \\ \text { CPF } & \text { Community Policing Forum } \\ \text { DA } & \text { Democratic Alliance } \\ \text { GEAR } & \text { Growth Employment and Redistribution } \\ \text { GPF } & \text { Gauteng Partnership Fund } \\ \text { ICHUT } & \text { Inner City Housing Upgrading Trust } \\ \text { ICRC } & \text { Inner City Regeneration Charter } \\ \text { ICRM } & \text { Inner City Road Map } \\ \text { JDA } & \text { Johannesburg Development Agency } \\ \text { JHC } & \text { Johannesburg Housing Company } \\ \text { JOSHCO } & \text { Johannesburg Social Housing Company } \\ \text { JSDF } & \text { Johannesburg Spatial Development Framework } \\ \text { NASHO } & \text { National Association of Social Housing Organisations } \\ \text { NGO } & \text { Non-Governmental Organisation } \\ \text { NHFC } & \text { National Housing Finance Corporation } \\ \text { RCID } & \text { Residential City Improvement District } \\ \text { RDP } & \text { Reconstruction and Development Programme } \\ \text { TUHF } & \text { Trust for Urban Housing Finance } \\ \end{array}$


This page intentionally left blank 


\section{Thinking with and through Johannesburg}

\section{Introduction}

This is a book about urban change. Cities are dynamic, ever-changing places. As such, they require agile, flexible theoretical lenses and analytic repertoires (Robinson, 2016). But the change which occurs in each specific city is not open-ended or indeterminate. Cities change within the bounds established by their histories, the contemporary socio-political juncture at which research is taking place, and within enduring topographies and physical spaces. This book, then, is about understanding the ways in which processes of urban change unfold in a specific place, with a specific set of histories and dynamics. It pays close attention to the urban regeneration project currently underway in Johannesburg's inner-city, and seeks to understand the range of factors and actors which have come together to shape the process and the effects that it is having on the lived realities unfolding in the area, 24 years since the end of apartheid. The research and discussion cover several areas and topics, focusing on policy formation and the relationship between state intervention, ideologies of redistribution and market-based approaches to urban redevelopment; a sociological study of various housing developers and investors; an examination of everyday policing and security provision in a fraught, stressed urban environment; and a reflection on the lives and experiences of lower-income residents who make the area home. The book attempts to tie these different strands together to develop a fuller picture of experiences of urban change, and to understand what they mean in the context of the post-apartheid city.

Although the book is focused on a specific case, the world of cities is not fragmented, and there is increasing recognition that cities everywhere are linked through relational networks, connections and flows of people, capital and ideas. In examining one particular process of change, the book also asks what can be learnt from Johannesburg that can help us understand dynamics in other places too. It therefore explores the relationship between specificity and generality, and the extent to which it is possible to develop theory which can travel from one individual (although certainly not bounded or isolated) case to speak to and aid in making sense of other settings and localities. It is thus an attempt to apply, as well as explore the limits of, a comparative imagination. 


\section{Thinking with and through Johannesburg}

Speaking to elsewhere from Johannesburg is certainly not an obvious or straightforward undertaking. Although iconic, Johannesburg is, on the surface, far from the norm. It is a city which is most frequently noted for its archetypal extremes - its alarming inequalities, distorted and fragmented urban form, severe levels of violence and stark, enduring racial divide. These are all certainly specific problems which affect life in the city and continue to harm many of its approximately five million residents. However, these are also problems which are not unique to Johannesburg. Fear of violence and insecurity, racial discrimination, rising inequalities and housing shortages are shared experiences for urban dwellers across the globe. Thus, insights gained in Johannesburg do not only speak to the immediate context, but can be helpful for thinking through or analysing other places too. At the same time, Johannesburg is an ordinary city like any other, where people, both despite of but also because of the abovementioned disparities and forms of violence, go about their everyday lives, seeking ways to feel safe, to raise their families, to find work and shelter, to build homes, to connect with others and to get on with not only surviving, but also making the most of life. Some people also engage in the extremely difficult work of making the post-apartheid city better, of attempting to develop housing, enact planning procedures which mitigate fragmentation and exclusion, create employment, govern the city for all its residents, care for friends and family, and even heal racial divides. It can be instructive, then, to look more closely at how people undertake these endeavours in an 'extreme' context, to both reveal some of the difficulties which characterise life in other places too, but also to learn about the creativity, urgency and innovation which go into urban governance, and that make up and sustain everyday lives.

\section{The not-so-extreme city}

Whilst undertaking the research which informs this book, I found my way into a range of different places. Buildings, parks, recreation facilities, churches (some of which used to be synagogues), streets crowded with people, the back of a police van (also crowded with people), shopping malls, a gym, corporate offices and homes. Some of these places certainly exemplified the 'extremes' which Johannesburg is noted for. For example, Pullinger Kop Park, located on the eastern edge of Hillbrow, is a desolate patch of land and widely known 'hotspot' where drugs are easily available. Built on a plot that was once the stately home of a man who made his fortune in the brutally exploitative mining industry, and still bearing his name, it underscores how the country's system of racialised capitalism generated luxury and vast sums of wealth for some people, whilst simultaneously impoverishing the black ${ }^{1}$ majority and leaving ruination in its wake (cf. Stoler, 2008). As the 20th century unfolded, the wealthy elite moved away from the central city and began to settle in the city's northern expanses. The land on which Pullinger's house rested was donated to the City and turned into a public park. The movement of wealthy white people away from the central city prefigured the area's decline and the destruction of most public infrastructure 
in the vicinity. The fate which befell the park thus also clearly shows how capitalism uses people and places, and then discards them once value can no longer be extracted from them (Chari, 2017).

Today, the park is in a severely dilapidated state. When I visited, it was a cold Saturday night in the middle of the bitter Highveld winter. Despite the cold, the park was crowded with people, the majority of them homeless, buying and using the available drugs, and then retreating to the cardboard boxes and assorted blankets which served as their makeshift homes. The scene in the park underscored the severe, seemingly intractable problems which continue to define many people's lives in Hillbrow. It made vivid the ways in which chronic poverty, unemployment and homelessness are the reality for far too many people, despite the city's general wealth and prosperity. It also clearly demonstrated how people, lacking any other forms of social and physical support, depend on cheap, harmful substances to make it through the cold night, as well as how others, lacking other employment opportunities, prey on their vulnerability to earn income. The events unfolding in the park also brought home the ostensible impossibility of governing and improving the inner-city. The bulk of the drug trade was taking place in a basketball court which had been installed in the park during a previous attempt to improve the neighbourhood; the only remaining traces of the improvement effort were a sign announcing the 'Pullinger Kop Revitalisation Project,' which had long-since been effaced and scribbled over, the rims of the baskets at each end of the court - the supporting structures having been thoroughly stripped of any metal or other useable material - and the paved surface that people were bedding down on for the night. The despondency of the situation was overwhelming, and I found myself at the limits of my theoretical vocabulary and ability to make analytic sense of it all. At that point, my eyes fell upon a piece of writing scrawled in a shaky hand onto the 'renewed' surface of the basketball court. In large black letters, someone had written the word 'FUCK,' which, I had to admit, was the most eloquent way of summing up the situation.

Although Pullinger Kop was a particularly difficult, disturbing setting and vivid reminder of Johannesburg's discarded people and spaces, it was also just one of many different spaces which make up the inner-city. Another park, also located in Hillbrow, captures some of the significant changes which have taken place, but also the mundane, but no less significant, effects they have had. Ekhaya Park, which features prominently in latter chapters, is a place I grew familiar with and often look back on fondly. Jointly funded by the Ekhaya Residential City Improvement District, the Johannesburg Development Agency and FIFA's World Cup legacy programme, it is an AstroTurf football pitch surrounded by a tall wire fence and accompanied by a playground and sets of benches. It was built on a plot of land which, like many other spaces in the neighbourhood, had fallen into disuse. I attended several Ekhaya Kidz Soccer Days at the park, where teams comprised of children from surrounding residential buildings compete in day-long tournaments, cheered on by their carers and neighbours. These days were always heart-warming occasions, and offered powerful juxtapositions to the desolation of the other park. Even on 


\section{Thinking with and through Johannesburg}

days when there weren't organised events taking place, the football pitch was always in use, with children playing, shouting and just enjoying being kids, in what was once one of the most dangerous, violent neighbourhoods in the city (Leggett, 2003).

Whilst not taking away from the exclusion, suffering and hardships which characterise life for far too many of Johannesburg's residents - particularly those who shelter in the city's derelict buildings, its parks (in the inner-city and suburbs) and in the informal settlements which dot the city's periphery, but have also sprung up in some abandoned warehouses and industrial buildings on the edge of the inner-city - it is the ordinary, not-so-extreme spaces, such as Ekhaya Park, that I want to draw attention to. When writers describe Johannesburg as a 'city of extremes' (Murray, 2011), they draw our attention to the continuing racial disparities and inequities which define contemporary South Africa, and the ways these are expressed through the divide between spaces of (predominantly white) privilege, such as pristine, exclusive shopping malls, fortified, luxurious gated communities, insulated office parks and corporate skyscrapers, and homelessness, informal settlements, chronic, lifelong unemployment and relative deprivation, particularly in the former black townships. Whilst disturbing, these stark visions fail to include the in-between, not-so-extreme spaces that also make up the city. Whilst a lot of my research took place in public spaces, including the two parks discussed above, a great deal was also carried out inside residential buildings. These interiors offer important insights into the combination of somewhat drastic measures and approaches to security which define the regeneration process, as well as the ordinary, everyday lives which are unfolding inside them.

Places which stand out in my mind, several years after the bulk of the research was conducted, include a freshly painted, open-plan room, with a small built-in sink and hotplate that was the soon-to-be home of two adult men, both of whom work as security guards and need a way to stretch their meagre salaries; a largely empty, two-bedroom apartment in Hillbrow whose long-faded parquet floors recalled the previous glamour and desirability of the neighbourhood, where, for want of other furniture, my host and I sat on upturned beer crates as we discussed life in the area; a one-bedroom flat where the living room doubles as a stay-at-home father's office and his young child's bedroom; another one-bedroom flat where a large cabinet, complete with a flat-screen TV and speaker system, serves as a divider between the living room and children's bedroom. These spaces stand out for several reasons: firstly, they demonstrate the flexibility which is required to make homes in the inner-city - sub-dividing apartments, sharing a room with a friend, relative or colleague, sacrificing privacy in order to afford central, well-located accommodation - as well as the work that goes into making a life - filling a room with objects such as televisions, speakers, couches, religious artefacts, but, more importantly, carving out a space of quiet and safety where children can be raised and weary bodies can be rested, away from the constant noise, bustle and movement of the throbbing streets outside. 
Secondly, paying attention to the everyday ways in which people construct homes for themselves draws attention back to the agency which people possess in all areas and facets of life, and which often gets neglected in extreme accounts of relentless poverty and suffering (Back, 2015). Accounting for these forms of agency is not intended to detract from broader structural problems, including institutionalised racism and inequality, enduring patterns of colonial violence and dispossession, and the damage wrought by neoliberal governance agendas. It is, however, intended as a salve to the more despairing images of life in the postapartheid period, where constant emphasis on policy failures, inefficiency and corruption, governmental neglect and profit-driven ideologies frequently obscure the ways in which millions of people's lives have changed for the better. These narratives also discredit the ingenuity and experimentalism which are part and parcel of urban life, and the shifting roles and identities which people adopt as they try to make meaningful improvements to the city. Lastly, attending to the not-so-extreme spaces of the city helps situate the experiences of black urban dwellers in the story of ordinary cities around the world (Robinson, 2006), and demonstrates that the lives which people construct in African urban contexts are not only shaped by the extremes of poverty, deprivation and injustice (although these are central parts of the story), but are also based on mutual support, care and simple efforts to get by. Because they are less extreme than we are often led to believe, the lives people lead and choices they make are also marked by practices and lessons which people concerned with other contexts can draw on, relate to, and learn from.

\section{Situating Johannesburg's inner-city}

\section{Socio-political landscape}

The interiors I am describing above are important because of their physical and socio-political location. Johannesburg's inner-city has always exemplified and materialised the trends which have shaped the country at its various stages of existence. The modern city, seen from above in Figure 1 below, grew out of the gold rush at the end of the 20th century, and bore the hallmarks of this lucrative, but also highly extractive, violent and exploitative industry. The richest seam of gold ever discovered gave birth to a city at the forefront of modernity, as skyscrapers quickly begun to sprout on a once dry, dusty patch of land (Beavon, 2004; van Onselen, 2001). Street names such as Prospect, Nugget, Claim and Quartz still pay homage to the mining industry and mark the area's geography and people's routes through it (Nuttall, 2004). Less visible, however, are the places of harassment, imprisonment and violence which constituted the black population's experiences of the colonial and apartheid city. Although memorialised in places such as Constitutional Hill and the Drill Hall, the everyday violence and oppression which marked the city and through which its 'European'2 character was kept intact are not always readily apparent. However, the scrutiny, policing and exclusion which black people were subjected to did as 


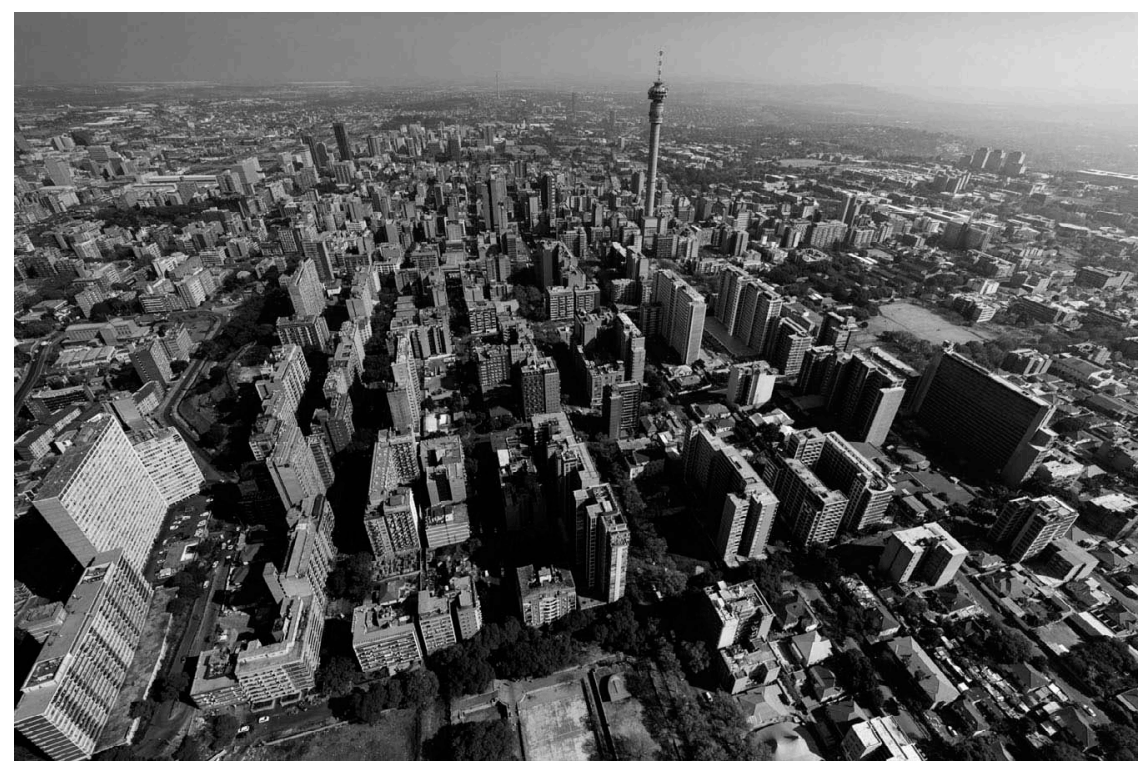

Figure 1.1 Aerial image of inner-city. Photograph by Clive Hassel.

much to define the city as its burgeoning wealth and glamour (Mbembe, 2008). In that sense, Johannesburg has always intertwined two elements: modernism, aspiration, commerce and wealth, on the one hand, and brutality, repression, white racism, exploitation and subjugation, on the other.

Riding on the high price of gold, the city flourished through the middle decades of the 20th century. The wealth flowing from the mines became concretised in the city's built form, with older buildings being demolished and the bulk of the high-rise buildings and skyscrapers which make up the city's contemporary skyline dating from this period, through to the 1970s (Chipkin, 1993). However, as the apartheid regime's grip on power became increasingly unstable, the fortunes of the inner-city began to decline too. Downturns in the price of gold, international sanctions, deindustrialisation without concomitant reinvestment, and political insurrection all put pressure on the apartheid government and began to change the fabric of the central city. As investors grew wary about the political situation, they began to move away from the inner-city, with factories, warehouses and shops closing down, corporate headquarters beginning to relocate and wealthier white residents leaving for the leafy suburbs (Beavon, 2004; Goga, 2003; Morris, 1999a). Whilst this process of flight had deleterious consequences for the built environment, with neglect and ruin becoming increasingly prevalent, it also signalled a broader change. Before apartheid officially came to an end, more and more black people began to move into the inner-city. 
What was once the bastion of white, European urbanity started to more closely reflect the African context in which the city is situated. Newly arriving residents marked the inner-city with their presence, and a new sense that the city was moving away from, but still very much influenced by, its European, racist origins took hold (Mbembe and Nuttall, 2008; Tomlinson et al., 2003).

When apartheid formally came to an end in 1994, Johannesburg's inner-city was markedly different, demographically, but also in terms of how the built environment was used and lived in. In a short space of time, wealthy white people were replaced by black residents, who were generally poorer, and many could only afford the rents being charged by sub-letting and sharing rooms with far more people than they were originally built to house (Crankshaw and White, 1995; Morris, 1997). Landlords who remained in the area (and didn't simply abandon their properties in the face of drastic capital flight and residential change, as many did) exploited their tenants and the growing demand for accommodation, charging high rentals and not investing in any maintenance or upkeep (Morris, 1999b). The area's economy also changed, with corporate and financial services giving way to small-scale manufacturing and survivalist trading. These changes infused the area with a different character, but also brought enhanced governance challenges, forms of poverty and deprivation, struggles over space and rights to belong, and crime and violence. At the same time, the changes which were affected also recreated formerly segregated places like Hillbrow, Berea and Yeoville as sites of emancipation, mobility, adaptation and experimentation (Gotz and Simone, 2003). As these changes are lived out in the shadows of the former colonial and apartheid urban landscape, Johannesburg has come to embody the hopes, optimism and dynamism, but also the challenges, legacies, inequities and forms of deprivation which define South African urban modernity. Today the city stands as a representative of both South Africa's apartheid past, as well as its uncertain, still-emerging postcolonial present.

Perhaps more than any other setting in Johannesburg, the inner-city demonstrates the changes which have occurred since the end of apartheid. Today, it is a mix of old and new infrastructures and is animated by a diverse population. In a generally dispersed urban landscape, it is densely populated, accounting for roughly $12 \%$ of the City of Johannesburg's population (of almost five million) (HSRC, 2014). Although the area has been largely abandoned by corporate South Africa, it still has an immense economy, with vast amounts of commodities and cash circulating through it on a daily basis (Zack, 2016). Whilst South Africa's major banks maintain offices in the area, they have all relocated their corporate headquarters to other, more illustrious parts of the city. Anglo-Gold Ashanti, one of the largest gold producers in the world, have remained in the area, basing themselves in Marshaltown, a banking district which has emerged on the site of the original town centre, and where an open-air museum commemorates the city's inextricable link with gold mining. Outside of this small precinct, smallscale manufacturing, motor mechanics and trading, both formal and informal, are the predominant forms of economic activity. 


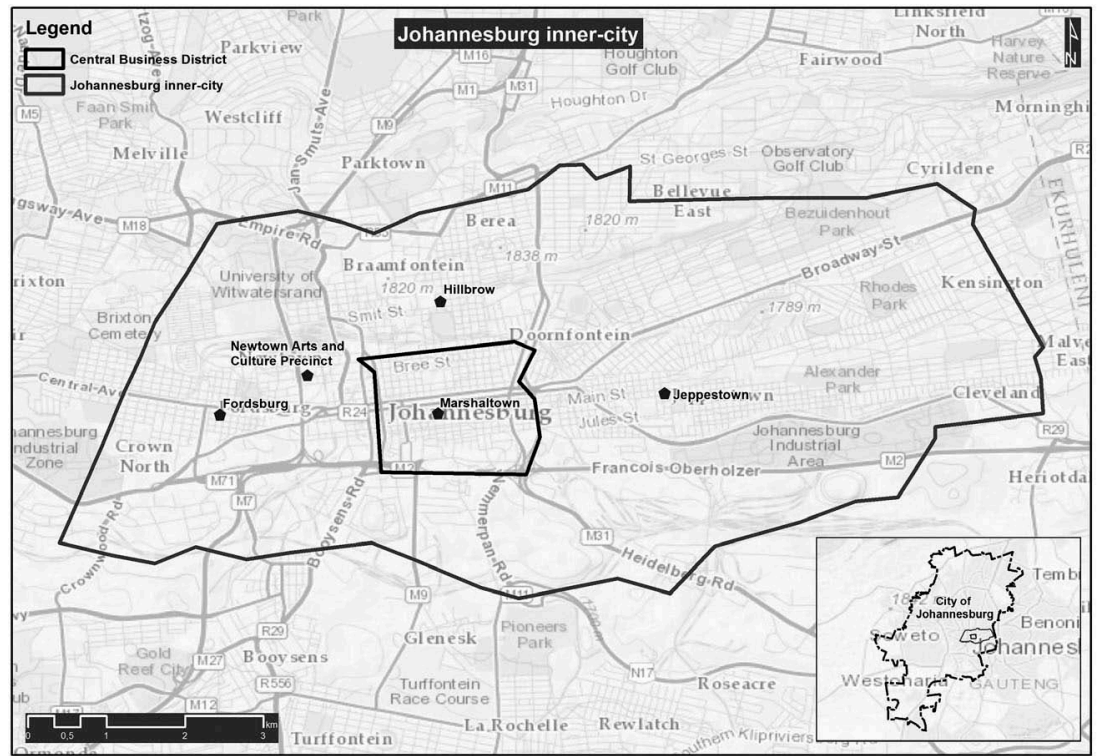

Map 1.1 Map of inner-city.

The inner-city's social geography is diverse. Various populations have imprinted their presence on distinct areas: Fordsuburg, on the western side of the inner-city, is a semi-industrial, low-density suburb traditionally home to South Africans of Indian origin. It boasts a number of restaurants and cafes purveying Indian cuisine, and Bollywood movies and assorted paraphernalia are widely available. More recently, migrants from Pakistan, Bangladesh and Somalia have settled there, drawn to its mosques and Islamic community organisations (Dinath et al., 2014; Jinnah and Rugunanan, 2016). Running eastwards, Braamfontein is a commercial district with a large supply of high-rise office space. It is also increasingly providing accommodation for students, as the University of the Witwatersrand is located within this district and the University of Johannesburg is also nearby. The burgeoning student population has attracted new investments, and several popular bars, entertainment venues, boutique shops and markets have opened in recent years. This area has captured local and international attention, and tourists, aspirant photographers, filmmakers and artists have become ubiquitous. However, whilst the area profits from the presence of the universities and their students, fractious political movements and events originating in the universities have affected the broader vicinity too. In 2016, demonstrations over the costs of higher education at the University of the Witwatersrand spilled out into the streets surrounding the university, and the police fought running battles with students throughout 
Braamfontein. The police fired numerous rounds of teargas and rubber bullets, several buses were set ablaze and some shops were looted. ${ }^{3}$ These events were reminders that frustrations with ongoing inequality, blocked social mobility and persistent institutionalised racism cannot be confined to the universities, and are increasingly part of South Africa's urban fabirc. In this case, the city was not just a setting, but a vital staging ground through which these politics could be expressed.

The politics of the moment also play out in the spaces of the Central Business District (CBD). This was originally the centre of the economy during the gold mining era, home to numerous corporate headquarters, financial firms and mining companies. Today it is a mixed-use area, comprising commercial and retail services, both formal and informal, as well as residential buildings and the city legislature. As white South African-owned businesses have vacated the area, different groups of African migrants have come to capitalise on the commercial opportunities available. Jeppe Street, for instance, has attracted a host of Ethiopian businesses and traders. Known colloquially today as 'Little Addis,' entire buildings have become home to shops and warehouses trading in goods from East Africa, including coffee, spices, Ethiopian music, cooking utensils and clothes. In these spaces, the ways the city has been reabsorbed into the African continent become palpable. The effects of migration from the rest of the continent also make themselves felt in and around the Central Methodist Church. Neighbouring the Johannesburg High Court, the church has become a place of refuge for migrants, predominantly from Zimbabwe. In 2008, people fleeing outbreaks of violence targeting African migrants found their way to the church, which opened its doors and became a makeshift refugee centre. Xenophobic hostility towards other Africans has not yet subsided, and the church continues to shelter countless people, much to the chagrin of local government and the neighbouring legal professionals, businesses and property owners (Kuljian, 2014).

Demographic, economic and social change are also palpable in the high-rise suburbs of Hillbrow and Berea, which adjoin the CBD on its north-eastern edge. Occupying an area roughly $2 \mathrm{~km}^{2}$, these areas have some of the highest residential densities in the entire city and are presently home to approximately 200000 people. Whilst they were originally established to house the white population employed in and around the $\mathrm{CBD}$, today they are home to a predominantly black African population, comprising South Africans as well as migrants from other African countries, mostly Zimbabwe and Nigeria. Hillbrow is a particularly notorious area and is known throughout South Africa, by black and white people alike, for its high levels of crime, violence, sex work and drugs. North of Hillbrow are the lower-density residential suburbs of Yeoville and Bellevue, which are also home to large migrant populations, predominantly from the Democratic Republic of Congo (Prabhala, 2008). The northern edge of Yeoville is framed by Louis Botha Avenue, one of the main thoroughfares in Johannesburg, which runs all the way from the inner-city to Alexandra township in the north-east of the city. It is one of the busiest roads in the country and has become part of the ambitious Transit Oriented Development strategy currently being implemented in various sites across the city (see Rubin and Appelbaum, 2016). 
The eastern side of the inner-city is largely made up of warehouses and factories. Ellis Park Stadium, the site of South Africa's famous victory in the 1995 Rugby World Cup, and the Johannesburg Athletics Stadium are also located in the industrial suburb Doornfontein. Jeppestown is a suburb in the eastern part of the inner-city and is proliferated with disused industrial buildings. The city's disturbing poverty makes itself felt here, as many of these buildings have become people's homes, despite lacking ventilation, water and electricity (Mayson and Charlton, 2015). At the same time, the section of Jeppestown closest to the CBD is home to the Maboneng Precinct, an area in which former industrial buildings have been converted into artists' and fashion designers' studios, high-end retail outlets, restaurants and residential units. It currently occupies $150000 \mathrm{~m}^{2}$ and houses roughly 500 residents, but the developers have ambitious expansion plans (Propertuity, 2013). The area south of the CBD and Jeppestown is known as City Deep. It bears the strongest traces of the city's mining industry and is proliferated by disused mining land and the city's iconic mine dumps which, along with the freeway, also form the southern border of the inner-city. Despite highly toxic soil and water, communities of worshippers have claimed spaces around the abandoned mines, establishing churches and holy sites for themselves, thus reanimating spaces of exploitation, abandonment and ruin and investing them with new hopes, dreams and aspirations (Malcomes and Wilhelm-Solomon, 2016).

\section{Decline and revitalisation}

All of the changes which have taken place in the inner-city were made possible by a preceding, drastic process of capital flight and decline. Beginning in the 1980s, white-owned businesses began to relocate away from the inner-city. As international sanctions began to bite and internal political activism made apartheid increasingly untenable, many investors started to feel uncertain about the country's political and economic stability. Simultaneously, increasing numbers of black people began to move into inner-city neighbourhoods which were deemed off-limits to them. They were compelled to move away from the racially designated townships where housing shortages were reaching critical dimensions (Crankshaw and White, 1995). Furthermore, following the 1976 student uprisings in Soweto, the political climate in the townships had become increasingly fractious and these areas became intense sites of conflict between residents and the apartheid security forces. They became increasingly volatile and riven by police brutality and violence between different political factions, prompting many of those who could afford to live elsewhere to leave.

Initially Indian and coloured people began to move into inner-city suburbs such as Hillbrow. The majority who settled in Hillbrow in this period were middle class, and were generally employed in clerical and administrative roles (Crankshaw and White, 1995). Over time, they were followed by greater numbers of Black Africans. Due to apartheid's systematic differentiation according to racial categories, Black Africans were (and continue to be) the most impoverished group in South Africa. Those who moved into Hillbrow at this 
stage were therefore less educated and earned lower salaries than the Indians and coloureds who arrived before (ibid.). Faced with increasing changes in the area, white residents began to leave in great numbers. Not only were they motivated by fears couched in racism, they were also enticed by the government's policy of providing financial incentives for aspiring white professionals to move into the decentralised suburbs, particularly in the northern regions of the city (ibid.).

In growing numbers, black people in dire need of accommodation rushed in to fill the openings created by fleeing white residents, despite the threats of removal they faced from Influx Control and Group Areas laws. ${ }^{4}$ Many landlords were quick to seize on the opportunities presented by the new demand for inner-city accommodation, some capitalising on the precarious situation of their newly arrived tenants, exploiting them by overcrowding apartments and refusing to maintain their properties (Morris, 1997). A spiral of neglect and destruction ensued, leading to the development of slum-like conditions in many inner-city buildings. Financial institutions exacerbated the situation as, growing increasingly jittery about the fate of the inner-city, they began red-lining the area, refusing to provide finance for property investments. As a result, owners wishing to maintain their buildings frequently could not raise the capital to do so, and higher-earning people were disincentivised from remaining in or moving into the area. Influx control laws were eventually repealed in 1986, greatly accelerating the movement of black people, particularly Black Africans, into the inner-city and causing the demographic composition and character of the area to change fundamentally (Morris, 1999c).

Whereas in 1986 only roughly 20000 of Hillbrow's 120000 residents were black, by $199385 \%$ of the residential population was black and by 1996 only $5 \%$ was white (Tomlinson et al., 2003). This was a pattern repeated in the central regions of cities throughout South Africa, as apartheid began to be dismantled and new urban patterns started to arise (see Maharaj and Mpungose, 1994). Faced with declining infrastructure, the increased presence of populations previously regarded as 'undesirable' and un-urban (Robinson, 1996) and rapidly spreading crime and grime, the flight of businesses and capital from Johannesburg's inner-city accelerated, culminating in 1998 in the relocation of the Johannesburg Stock Exchange to Sandton, a rapidly expanding commercial suburb in the north-eastern part of the city. This was also a period in which property speculation in the northern regions of the city was growing and investors were increasingly being encouraged by local government to look to suburbs like Sandton for new opportunities and profits (Goga, 2003). The decision to move the Stock Exchange confirmed the ascent of the northern districts of the city as the new financial centre and effectively delivered the 'knockout blow' to the old CBD (Beavon, 2004, p. 259), leaving it to fall further into disrepute and decay.

There have been several efforts to arrest the decline, some more successful than others. Early efforts aimed at turning the inner-city into both a trading hub, imaging it as the 'gateway to Africa,' and a high-tech financial centre (Bremner, 2000). These ambitious plans have given way to more pragmatic, but, as will be argued throughout this book, more durable and substantial renewal plans. The 
revitalisation efforts which have had enduring effects on the inner-city, and which this book is concerned with, have focused on the provision of social and affordable housing, largely through refurbishing or converting disused and derelict residential or commercial buildings. The social housing sector is dominated by private, non-profit companies, although there are several state-owned social housing institutions active around the country, including the Johannesburg Social Housing Company (JOSHCO), who are based primarily in and around the inner-city. Social housing caters to households whose salaries are above the maximum requirement to qualify for free state-provided housing, but remain unable to access accommodation through commercial markets. On current figures, those qualifying to be housed by social housing institutions earn between R3500 and R7000 per month. Domestic workers, security guards, waiters, shop assistants, low-skilled manual labourers or self-employed informal traders or craftsmen are frequently tenants in social housing developments.

Affordable housing is a more controversial category. Private companies branding themselves as 'affordable' make up the bulk of the formal rental market in the inner-city. Their rentals are targeted at households earning between R3500 and R14000 per month, and generally appeal to people employed in stable but low-paying jobs, such as teachers, police officers, professional assistants, nurses, call-centre workers and bank tellers. However, the 'affordability' of these offerings is questionable. Income levels vary within the inner-city: there is a sizeable low-to-moderate income population, as $21 \%$ of inner-city households earn monthly salaries between R3500 and R7500; there is also a growing segment that can be thought of as middle class, with $17 \%$ earning between R6366 and R12816 per month. However, 49\% of inner-city households earn less than R3200 per month and there is a 25\% unemployment rate (SERI, 2013). Thus, whilst a significant proportion can afford the rents being charged, privatesector accommodation is beyond the reach of the bulk of population residing in the area. The discrepancy between the rents charged and what people can actually afford to pay has led inner-city residents to find alternative, improvised living arrangements, including under bridges, in derelict buildings lacking water and electricity connections, and in former industrial buildings which have been haphazardly converted into living spaces (Mayson and Charlton, 2015).

At the same time, as I will demonstrate, housing providers too have had to adjust to the inner-city's realities and find inventive strategies for navigating between commercial demands and the constraints faced by the bulk of the people who call the area home. These acts of navigation, pragmatism and adaptation are at the core of my concerns in writing this book, as I seek to explore how pursuing urban regeneration in the context of Johannesburg's inner-city (and other locations too), requires flexibility, cognisance of the prevailing socio-spatial circumstances and inventiveness. Focusing on these activities helps make sense of the process underway, and account for, as well as critique, some of the effects that it is having on the area and the people living in it. As will hopefully become clear, the book aims at providing an inductive account of the regeneration process, drawing on the multiple motivating logics and agendas which have 
inspired it, the practical activities which go into grounding improvements in a volatile environment, and documenting the ways people live through and with processes of urban change. The overall goal is to emphasise the need for research to engage with and reflect local concerns, agendas and life-worlds, and to avoid over-reliance on pre-given categories or analyses. In turning to Johannesburg, I call attention to the ambiguity and diversity of processes of urban change and emphasise the unpredictability of vernacular experiences and practices everywhere.

\section{Contemporary urban governance: between neoliberalism and developmentalism}

By following the regeneration process underway in Johannesburg, this book aims to contribute to the burgeoning debates about urban developments in contemporary South Africa. South African cities have provoked a range of considerations and interventions. Studies have focused on numerous issues, not all unique to South Africa, but often presenting themselves in intense forms: increasing inequality and urban segmentation (particularly through gating and neighbourhood enclosures) (for example Clarno, 2013; de Vries, 2008; Dirsuweit and Wafer, 2006; Harrison et al., 2003; Murray, 2011); governing, or in some cases seeking to eradicate, informality (for example Lemanski, 2009; Mitchell and Heynen, 2009; Steck et al., 2013; Tissington, 2009); housing provision and policy shortcomings (for example Charlton, 2009; Charlton and Kihato, 2006; Huchzermeyer, 2001, 2014; Lemanski, 2006; Oldfield and Greyling, 2015); governance, policy and infrastructural innovations (for example Harrison et al., 2014; Harrison and Harrison, 2014; Rubin and Appelbaum, 2016; Todes, 2014); as well as increasing numbers of studies which engage with changing urban contexts through cultural and literary lenses (for example Charlton, 2017; Hlongwane, 2006; Matsipa, 2017). In terms of the urban policy literature, which this book draws on and aims to contribute to, there are two broad categories or schools of thought. The first focuses on the advent and effects of neoliberal interventions in the post-apartheid period. The second has arisen as a response to the former, and has come to stress the ongoing experimentation and developmental slant of governance in the contemporary period.

\section{Neoliberal urban governance after apartheid}

In the aftermath of its decay, Johannesburg's inner-city became the object of ambitious renewal plans. Broadly, these state-led initiatives sought to rebrand the area as the 'Golden Heartbeat of Africa' and a 'World Class African City' (Bremner, 2000). They thus sought to create an entrepreneurial environment which would attract local and overseas investment and are captured by the aspiration to World City status (Lipietz, 2008; Tomlinson et al., 2003). For many critics, these ambitions and the restructuring of local government 


\section{Thinking with and through Johannesburg}

which accompanied them clearly signal the advent of neoliberal forms of governance in the city. As Sihlongonyane (2015, p. 1620) concludes, the initial regeneration strategies developed for Johannesburg clearly signal the dominance of a pro-growth agenda and are 'inimical to the annihilation of economic inequalities.'

For instance, whilst the City Council's short-to-medium term planning and strategy document, iGoli 2010, emphasises the need for redistribution, equitable delivery of services and resources, and the enhancement of deprived people's access to economic opportunities, overall, the focus remains augmenting Johannesburg's competitiveness and attractiveness as an investment destination (Johannesburg Development Agency, 2010). Similarly, The Inner City Charter, the document which provides the basis for the renewal strategies undertaken in the 2000 s, firmly commits to a pro-growth agenda, and frames the underlying ambitions behind regeneration as increasing business opportunities and property values in the area (City of Johannesburg, 2007). In these ways, the strategies draw on and continue the path set out in the Growth, Employment and Redistribution (GEAR) macroeconomic programme. Adopted in 1996, GEAR emphasises the need for government to maintain fiscal discipline and focus on the costeffectiveness of its activities (Bond, 2000). It still maintains a commitment to social redress and the redistribution of economic wealth to communities excluded and impoverished under apartheid, but focuses on achieving these aims through 'trickle down economics,' where economic growth and competiveness are prioritised as the preconditions required to achieve wider social goals (Gumede, 2007). ${ }^{5}$ GEAR is also the framework which established privatisation as an official component of economic policy, focusing on the need to sell-off state assets, establish public-private partnerships and run state activities as profitable parastatals (ibid.). ${ }^{6}$

There are direct continuities between the principles of GEAR and those adopted by the City of Johannesburg in the late 1990s and early 2000s. For instance, following the restructuring process recommended by the strategic document iGoli 2002, the provision of municipal services has been taken over by utilities which are registered as separate companies, such as Johannesburg City Power, Johannesburg Water and Pikitup (which provides refuse removal, recycling and waste disposal services). These public-private companies operate on cost-recovery principles, and have replaced the idea of citizens entitled to rights and services with 'paying clients' consuming commodities (Barchiesi, 2007; Khan, 2000). This semantic and discursive shift has been accompanied by the introduction of punitive measures such as cutting off water and electricity services when people fail to pay and forcing communities to install pre-paid water and electricity meters (Desai, 2002).

Furthermore, urban governance in Johannesburg has become increasingly business-oriented, with the formation of specialist agencies who work alongside local government to manage the business affairs, developmental needs and rejuvenation of the city. Organisations such as the Central Johannesburg Partnership (CJP), Johannesburg Property Company (JPC) and Johannesburg 
Development Agency (JDA) are prominent in setting the direction and priorities of the city and serve to ensure cooperation between local government and the business sector (Lipietz, 2008). For instance, the JDA was established expressly for the purpose of encouraging partnerships between the City of Johannesburg and the private sector and encouraging businesses to invest in the city (Johannesburg Development Agency, 2010). It focuses on 'greenfield' projects designed to boost the image and attractiveness of the city (Viruly et al., 2010). This creates a situation in which regeneration projects prioritise capital and investors above the needs of ordinary citizens and low-income communities (Winkler, 2009).

Another clear, urban-level manifestation of the neoliberal, pro-business agenda has been the rise of City Improvement Districts (CIDs). CIDs are local variations of the Business Improvement Districts (BIDs) which have come to prominence in many Anglo-American cities. The adoption of this model in South Africa is symptomatic of the increasing authority of 'policy entrepreneurs,' who circulate globally and influence government agencies in policy formation and implementation (Peyroux, 2012, p. 178). CIDs are self-contained management districts which aim to improve predetermined geographic areas of the city by placing their day-today running and maintenance in the hands of independent, private boards. They are established when the majority of property owners and businesses within a circumscribed area agree to set up a non-profit management company. The company then charges every property owner in the defined area a levy, which is used to pay for top-up maintenance, cleaning and security services (Bénit-Gbaffou et al., 2012). Recent challenges to CID legislation in South Africa have made additional levies voluntary, but the model continues to be influential. CIDs have generally been successful urban management interventions and areas where they have been established have come to enjoy enhanced cleanliness and safety (Berg, 2004).

Significantly, however, CIDs are also increasingly criticised for the ways in which they fragment the urban landscape, introduce differential access to resources and services and pursue revanchist forms of urban management (Berg, 2010; Paasche et al., 2014; Peyroux, 2006). They also concentrate a great deal of decision-making and urban governance power in property owners' hands. Whilst the management boards established to run CIDs in theory consist of partnerships between residents, local government and property owners/the business sector, in practice, since voting rights are determined by the amount of property individuals own in the area and the amount contributed through levies, the more wealthy and powerful members come to have control (Bénit-Gbaffou, 2008). In Johannesburg, 'the City of Johannesburg openly acknowledges that it seldom participates in the central CID's management board' (Bénit-Gbaffou et al., 2008, p. 710), creating a situation in which the demands of the business sector are prioritised and they are given increased decision-making powers and control over space.

\section{Developmental imperatives}

The neoliberal policy and governance agendas have meant that, not only have the inequalities and injustices of the past endured, but new disparities and forms of 


\section{6}

Thinking with and through Johannesburg

deprivation have arisen in the post-apartheid period. Unemployment levels have increased dramatically as industry has stagnated and employment has become increasingly casualised. The white community continues to enjoy the largest share of wealth and income and also enjoys the highest living standards (Everatt, 2014). Although a small black elite and sizeable middle class have emerged, social mobility for some has been coupled with worsening economic prospects and quality of life for the majority of the country's citizens (Mushongera, 2017; Mushongera et al., 2017), leaving South Africa as one of the most unequal societies on the planet.

However, stress on the failings of the post-apartheid period can obscure many of the substantial gains and improvements which have been made since the end of apartheid. Particularly, it is worth highlighting how millions have been lifted out of poverty through government support and new access to employment and education opportunities (Seekings and Nattrass, 2005). The state has also succeeded in constructing new housing for the poorest members of society, providing homes for upwards of 11 million people (Tissington, 2009). Whilst pockets of deprivation and lack of necessities such as electricity, infrastructure and plumbing endure, these are the exception, rather than the norm. Furthermore, a substantial, progressive body of human rights has been codified in South African law, ensuring that all citizens, in theory at least, enjoy equal access to the law, education, basic needs such as housing, water and electricity, and are free to express their political opinions and sexual preferences. Although these steps have not alleviated the high levels of inequality, poverty and discrimination, they are positive developments in a country emerging from the shadows of racist authoritarian rule.

Constant depictions of post-apartheid policy and urban governance as 'neoliberal' also fail to recognise the array of innovations and practices that are simultaneously driving urban change (Harrison et al., 2014; Miraftab, 2007; Mosselson, 2017). For example, Houghton (2013) shows how the imperatives of global competitiveness and economic growth are entangled with the pursuit of post-apartheid redress and economic redistribution in the city of Durban's urban development strategies and projects. Similarly, Sihlongonyane (2015) demonstrates how Johannesburg's city development and branding strategies, whilst focused on commercial growth, are also deeply invested in attempts to promote new articulations of cosmopolitan but distinctly African urban identities, showcase 'black excellence' and disprove prevalent associations of Africa with despair, disfunction and governance failures. Furthermore, whilst some of the urban renewal policies in Johannesburg are indeed instantiations of neoliberal ideologies and practices, it needs to be acknowledged that these are constantly played out whilst local government tries simultaneously to address legacies and daily realities of social exclusion and widespread poverty (Parnell and Robinson, 2006, 2012). Whilst neoliberalism and rule by market forces are prevalent tropes in the post-apartheid period, struggles for equality and liberation are seldom absent from South African discourse and daily life (van Holdt, 2012a). 
Therefore, whilst government policies and programmes take on increasingly neoliberal forms, they retain commitments to redistributive and socially progressive goals. The South African state has also increased its spending on social welfare and support, and is today one of the largest middle-income welfare states in the world. Even with the increased neoliberal approach to governance and socio-economic life,

the provision of services and infrastructure to meet the basic needs of historically disadvantaged populations is a widely accepted priority of the post-apartheid government. Their provision, with that of housing, is a major if not the major fiscal commitment to anti-poverty activity in Johannesburg.

Beall et al. (2000, p. 114)

Reflecting these ambitions, the latest iteration of inner-city revitalisation strategies, the Inner City Transformation Roadmap, whilst maintaining the key progrowth commitments spelled out in the Inner Charter, emphasises the need for local government to find ways to address 'the ongoing need for accommodation for very poor residents and newcomers to the city' and highlights poverty and housing shortages as 'the most critical issues in the inner city' (City of Johannesburg, 2013, p. 6).

The policies and political programmes adopted in the post-apartheid period therefore cannot be simply classified or made to fit into one overriding narrative. Attention needs to be paid to the ways in which alternative discourses, new imaginations and possibilities exist alongside powerful structures and inequalities, and how the city itself is a field through which these competitions are played out (Isin, 2008). The different trajectories and policy programmes which have shaped Johannesburg in the contemporary period serve as powerful reminders and evidence that the post-apartheid social order, particularly as it is expressed and lived through cities, remains uncertain, hybridised and in-process.

Awareness of this uncertainty and hybridity sits at the heart of my analysis of dynamics in the inner-city. My contention throughout is that diverse strands and pressures push and pull urban societies in different directions and that singlesided causal explanations and evaluations should be avoided in favour of more rounded, context-sensitive and nuanced critiques. In making my case, I draw on the notion of simultaneity, as articulated by Henri Lefebvre. Simultaneity, as a concept and heuristic device, is central to Lefebvre's reading of cities. He uses it to emphasise the vibrant, contested and always multiple and shifting nature of the urban and to underscore how cities are spaces of multiplicity and becoming (Schmid, 2008). At the same time, the urban is also engendered and dominated by capitalism and its mode of production (Prigge, 2008). Hence cities are simultaneously spaces of creativity, difference and emergence, whilst also being spaces of domination, oppression and the crystallisation of inequality (Lefebvre, 2003). 


\section{Thinking with and through Johannesburg}

Atkinson, R. , Bridge, G. (Eds.), 2005. Gentrification in A Global Context: The New Urban

Colonialism . Routledge. London.

Back, L. , 2015. Why everyday life matters: class, community and making life liveable.

Sociology . 49, 820-836.

Ballard, R. , 2010. 'Slaughter in the suburbs': livestock slaughter and race in post-apartheid cities. Ethnic and Racial Studies . 33, 1069-1087.

Barchiesi, F. , 2007. Privatization and the historical trajectory of 'social movement unionism': a case study of municipal workers in Johannesburg, South Africa. International Labor and Working-Class History . 71, 50-69.

Beall, J. , Crankshaw, O. , Parnell, S. , 2000. Local government, poverty reduction and inequality in Johannesburg. Environment and Urbanization . 12, 107-122.

Beavon, K. , 2004. Johannesburg: The Making and Shaping of the City . University of South Africa Press. Pretoria.

Bénit-Gbaffou, C. , 2008. Unbundled security services and urban fragmentation in postapartheid Johannesburg. Geoforum . 39, 1933-1950.

Bénit-Gbaffou, C. , Didier, S. , Morange, M. , 2008. Communities, the private sector, and the state: contested forms of security governance in Cape Town and Johannesburg. Urban Affairs Review . 43, 691-717.

Bénit-Gbaffou, C. , Didier, S. , Peyroux, E. , 2012. Circulation of security models in southern African cities: between neoliberal encroachment and local power dynamics. International Journal of Urban and Regional Research . 36, 877-889.

Berg, J. , 2004. Private policing in South Africa: the Cape Town City Improvement District pluralisation in practice. Society in Transition . 35, 224-250.

Berg, J. , 2010. Seeing like private security: evolving mentalities of public space protection in South Africa. Criminology and Criminal Justice . 10, 287-301.

Bezuidenhout, A. , Khunou, G. , Mosoetsa, S. , Sutherland, K. , Thoburn, J. , 2007. Globalisation and poverty: impacts on households of employment and restructuring in the textiles industry of South Africa. Journal of International Development . 19, 545-565.

Bierschenk, T. , De Sardan, J.P.O. (Eds.), 2014. States at Work: Dynamics of African Bureaucracies . Brill. Leiden.

Bond, P. , 2000. Elite Transition: From Apartheid to Neoliberalism in South Africa. Pluto Press. Cape Town.

Bonner, P. , 1995. African urbanisation on the rand between the 1930s and 1960s: its social character and political consequences. Journal of Southern African Studies . 21, 115-129. Bourdieu, P. , 1984. Distinction: A Social Critique of the Judgement of Taste. Harvard University Press. Cambridge, Massachusetts.

Bourdieu, P. , 1990. The Logic of Practice. Stanford University Press. Stanford, California. Bourdieu, P. , 2005a. The Social Structures of the Economy. Polity Press. Cambridge. Bourdieu, P. , 2005b. Habitus, in: Hillier, J., Rooksby, E . (Eds.), Habitus: A Sense of Place. Ashgate. Aldershot, pp. 43-49.

Bremner, L. , 2000. Reinventing the Johannesburg inner city. Cities . 17, 185-193.

Brenner, N. , Schmid, C. , 2015. Towards a new epistemology of the urban? City . 19, 151-182.

Brenner, N. , Theodore, N. , 2005. Neoliberalism and the urban condition. City . 9, 101-107.

Bridge, G. , 2001. Bourdieu, rational action and the time-space strategy of gentrification.

Transactions of the Institute of British Geographers . 26, 205-216.

Butler, T. , Robson, G. , 2003. Negotiating their way in: the middle classes, gentrification and the deployment of capital in a globalising metropolis. Urban Studies . 40, 1791-1809.

Centner, R. , 2008. Places of privileged consumption practices: spatial capital, the dot-com habitus, and San Francisco's internet boom. City and Community . 7, 193-223.

Chari, S. , 2017. The Blues and the Damned: (Black) life-that-survives capital and biopolitics. Critical African Studies . 9, 152-173.

Charlton, E. , 2017. Melancholy mapping: a 'dispatcher's eye' and the locations of loss in Johannesburg. Thesis Eleven . 141, 14-30.

Charlton, S. , 2009. Housing for the nation, the city and the household: competing rationalities as a constraint to reform? Development Southern Africa . 26, 301-315. 
Charlton, S. , Kihato, C. , 2006. Reaching the poor? An analysis of the influences on the evolution of South Africa's housing programme, in: Pillay, U. , Tomlinson, R. , Du Toit, J. (Eds.), Democracy and Delivery: Urban Policy in South Africa. HSRC Press. Cape Town, pp. 252-282. Chipkin, C.M. , 1993. Johannesburg Style: Architecture \& Society, 1880s-1960s . David Philip Publishers. Cape Town.

City of Johannesburg , 2007. Inner City Regeneration Charter. City Council. Johannesburg. City of Johannesburg , 2013. Inner City Transformation Road Map . City Council. Johannesburg.

Clarno, A. , 2013. Rescaling white space in post-apartheid Johannesburg. Antipode . 45, 1190-1212.

Clarno, A. , Murray, M.J. , 2013. Policing in Johannesburg after apartheid. Social Dynamics . 39, 210-227.

Comaroff, J. , Comaroff, J.L. , 2012. Theory from the South: Or, How Euro-America Is Evolving toward Africa . Paradigm Publishers. Boulder, Colorado.

Cooper-Knock, S.J. , 2016. Behind closed gates: everyday policing in Durban, South Africa. Africa . 86, 98-121.

Crankshaw, O. , White, C. , 1995. Racial desegregation and inner city decay in Johannesburg. International Journal of Urban and Regional Research . 19, 622-638.

de Vries, F. , 2008. Megamalls, generic city, in: Nuttall, S. , Mbembe, A. (Eds.), Johannesburg: The Elusive Metropolis . Duke University Press. Durham, North Carolina, pp. 297-306.

Desai, A. , 2002. We Are the Poors: Community Struggles in Post-Apartheid South Africa . Monthly Review Press. New York.

Didier, S. , Peyroux, E. , Morange, M. , 2012. The spreading of the city improvement district model in Johannesburg and Cape Town: urban regeneration and the neoliberal agenda in South Africa. International Journal of Urban and Regional Research . 36, 915-935.

Dinath, Y. , Patel, Y. , Seedat, R. , 2014. Footprints of Islam in Johannesburg, in: Harrison, P. , Gotz, G. , Todes, A. , Wray, C. (Eds.), Changing Space, Changing City: Johannesburg After Apartheid. Wits University Press. Johannesburg, pp. 456-480.

Dirsuweit, T. , Wafer, A. , 2006. Scale, governance and the maintenance of privileged control: the case of road closures in Johannesburg's Northern Suburbs. Urban Forum . 17, 327-352.

Everatt, D. , 2014. Poverty and inequality in the Gauteng city-region, in: Harrison, P. , Gotz, G. , Todes, A. , Wray, C. (Eds.), Changing Space, Changing City: Johannesburg After Apartheid. Wits University Press. Johannesburg, pp. 63-82.

Gaule, S. , 2005. Alternating currents of power: from colonial to post-apartheid spatial patterns in Newtown, Johannesburg. Urban Studies . 42, 2335-2361.

Goga, S. , 2003. Property investors and decentralization: a case of false competition? in: Tomlinson, R. , Beauregard, R.A. , Bremner, L. , Mangcu, X. (Eds.), Emerging Johannesburg: Perspectives on the Postapartheid City . Routledge. New York, pp. 71-84.

Goonewardena, K. , 2008. Marxism and everyday life: on Henri Lefevbre, Guy Debord, and some others, in: Goonewardena, K. , Kipfer, S. , Milgrom, R. , Schmid, C. (Eds.), Space, Difference, Everyday Life: Reading Henri Lefebvre. Routledge. New York, pp. 117-133. Gotz, G. , Simone, A. , 2003. On belonging and becoming in African cities, in: Tomlinson, R. , Beauregard, R.A. , Bremner, L. , Mangcu, X. (Eds.), Emerging Johannesburg: Perspectives on the Postapartheid City . Routledge. New York, pp. 123-147.

Gotz, G. , Todes, A. , 2014. Johannesburg's urban space economy, in: Harrison, P. , Gotz, G. , Todes, A. , Wray, C. (Eds.), Changing Space, Changing City: Johannesburg After Apartheid . Wits University Press. Johannesburg, pp. 117-136.

Gumede, W.M. , 2007. Thabo Mbeki and the Battle for the Soul of the ANC . Zebra Press. Cape Town.

Habib, A. , 2013. South Africa's Suspended Revolution: Hopes and Prospects . Ohio University Press. Athens, Ohio.

Harrison, P. , Gotz, G. , Todes, A. , Wray, C. , 2014. Materialities, subjectivities and spatial transformation in Johannesburg, in: Harrison, P. , Gotz, G. , Todes, A. , Wray, C. (Eds.), Changing Space, Changing City: Johannesburg After Apartheid . Wits University Press. Johannesburg, pp. 2-39.

Harrison, P. , Harrison, K. , 2014. Soweto: a study in socio-spatial differentiation, in: Harrison, P. , Gotz, G. , Todes, A. , Wray, C. (Eds.), Changing Space, Changing City: Johannesburg After Apartheid. Wits University Press. Johannesburg, pp. 293-318. 
Harrison, P. , Huchzermeyer, M. , Mayekiso, M . (Eds.), 2003. Confronting Fragmentation: Housing and Urban Development in a Democratising Society. University of Cape Town Press. Cape Town.

Hart, G.P. , 2002. Disabling Globalization: Places of Power in Post-Apartheid South Africa . University of California Press. California.

Hlongwane, G. , 2006. 'Reader, be assured this narrative is no fiction': the city and its discontents in Phaswane Mpe's Welcome to Our Hillbrow. ARIEL . 37, 69.

Hoag, C. , 2010. The magic of the populace: an ethnography of illegibility in the South African immigration bureaucracy. PoLAR: Political and Legal Anthropology Review . 33, 6-25.

Houghton, J. , 2013. Entanglement: the negotiation of urban development imperatives in Durban's public-private partnerships. Urban Studies . 50, 2791-2808.

HSRC , 2014. The City of Johannesburg (COJ) Economic Overview: 2013. A Review of the State of the Economy and Other Key Indicators, Economic Performance and Development Programme (EPD). Human Sciences Research Council. South Africa.

Huchzermeyer, M. , 2001. Housing for the poor? Negotiated housing policy in South Africa. Habitat International . 25, 303-331.

Huchzermeyer, M. , 2014. Changing housing policy in South Africa, in: Bredenoord, J. , Van Lindert, P. , Smets, P. (Eds.), Affordable Housing in the Urban Global South: Seeking

Sustainable Solutions . Routledge. London, pp. 336-348.

Huchzermeyer, M. , Haferburg, C. , 2017. Redlining or renewal? The space-based construction of decay and its contestation through local agency in Brixton, Johannesburg, in: Kirkness, P. , Tije-Dra, A. (Eds.), Negative Neighbourhood Reputation and Place Attachment: The Production and Contestation of Territorial Stigma . Routledge. London, pp. 60-80.

Isin, E.F. , 2008. The city as the site of the social, in: Isin, E.F. (Ed.), Recasting the Social in Citizenship . University of Toronto Press. Toronto, pp. 261-280.

Jinnah, Z. , Rugunanan, P. , 2016. Remaking religion, rethinking space: how South Asian and Somali migrants are transforming ethnically bound notions of Hinduism and Islam in Mayfair and Fordsburg, in: Wilhelm-Solomon, M. , Nunez, L. , Kankonde Bukasa, P. , Malcomess, B. (Eds.), Routes and Rites to the City: Mobility, Diversity and Religious Space in Johannesburg.

Palgrave Macmillan. London, pp. 137-162.

Johannesburg Development Agency , 2010. Johannesburg Development Agency Annual

Report 2010/11 . Johannesburg Development Agency. Newtown, Johannesburg.

Kelly, P. , Lusis, T. , 2006. Migration and the transnational habitus: evidence from Canada and the Philippines. Environment and Planning A . 38, 831-847.

Kenny, B. , 2004. Selling selves: East Rand retail sector workers fragmented and reconfigured. Journal of Southern African Studies . 30, 477-498.

Kenny, B. , Webster, E. , 1998. Eroding the core: flexibility and the re-segmentation of the South African labour market. Critical Sociology . 24, 216-243.

Khan, F. , 2000. iGoli 2002 - is the future private? Green Left Online .

Kipfer, S. , 2008. How Lefevbre urbanized Gramsci: hegemony, everyday life, and difference, in: Goonewardena, K. , Kipfer, S. , Milgrom, R. , Schmid, C. (Eds.), Space, Difference, Everyday Life: Reading Henri Lefebvre. Routledge. New York, pp. 193-211.

Kuljian, C. , 2014. The Central Methodist Church, in: Harrison, P. , Gotz, G. , Todes, A. , Wray, C. (Eds.), Changing Space, Changing City: Johannesburg After Apartheid . Wits University Press. Johannesburg, pp. 494-497.

Lees, L. , 2012. The geography of gentrification: thinking through comparative urbanism.

Progress in Human Geography . 36, 155-171.

Lees, L. , Shin, H.B. , López-Morales, E. (Eds.), 2015. Global Gentrifications: Uneven

Development and Displacement. Policy Press. Bristol.

Lees, L. , Shin, H.B. , López-Morales, E. , 2016. Planetary Gentrification . Polity Press. Cambridge.

Lefebvre, H. , 1991. The Production of Space . Blackwell Publishers. Oxford.

Lefebvre, H. , 2003. The Urban Revolution. University of Minnesota Press. Minnesota.

Leggett, T. , 2003. Rainbow Tenement: Crime and Policing in Inner Johannesburg (Monograph

No. 78) . Institute for Security Studies Criminal Justice Monitoring Project. Pretoria.

Lemanski, C.L. , 2006. Desegregation and integration as linked or distinct? Evidence from a previously 'white' suburb in post-apartheid Cape Town. International Journal of Urban and Regional Research . 30, 564-586. 
Lemanski, C.L. , 2009. Augmented informality: South Africa's backyard dwellings as a byproduct of formal housing policies. Habitat International . 33, 472-484.

Ley, D. , 2003. Artists, aestheticisation and the field of gentrification. Urban Studies . 40, 2527-2544.

Lipietz, B. , 2004. Muddling through: urban regeneration in inner-city Johannesburg. NAERUS Annual Conference. Barcelona.

Lipietz, B. , 2008. Building a vision for the post-apartheid city: what role for participation in Johannesburg's City Development Strategy. International Journal of Urban and Regional Research . 32, 135-163.

Maharaj, B. , Mpungose, J. , 1994. The erosion of residential segregation in South Africa: the 'greying' of Albert Park in Durban. Geoforum . 25, 19-32.

Mamdani, M. , 1996. Citizen and Subject: Contemporary Africa and the Legacy of Late Colonialism . Princeton University Press. Princeton, New Jersey.

Marom, N. , 2014. Relating a city's history and geography with Bourdieu: one hundred years of spatial distinction in Tel Aviv. International Journal of Urban and Regional Research . 38, 1344-1362.

Matsipa, M. , 2017. Woza! Sweetheart! On braiding epistemologies on Bree Street. Thesis Eleven . 141, 31-48.

Mayson, S.S. , Charlton, S. , 2015. Accommodation and tenuous livelihoods in Johannesburg's inner city: the 'rooms' and 'spaces' typologies. Urban Forum . 26, 343-372.

Mbembe, A. , 2008. Aesthetics of superfluity, in: Nuttall, S. , Mbembe, A. (Eds.), Johannesburg: The Elusive Metropolis . Duke University Press. Durham, North Carolina, pp. 37-67.

Mbembe, A. , Nuttall, S. , 2008. Introduction: Afropolis, in: Nuttall, S. , Mbembe, A. (Eds.), Johannesburg: The Elusive Metropolis . Duke University Press. Durham, North Carolina, pp. 1-33.

McMichael, C. , 2015. Urban pacification and 'blitzes' in contemporary Johannesburg. Antipode . 47, 1261-1278.

Merrifield, A. , 2006. Henri Lefebvre: A Critical Introduction . Taylor \& Francis. London.

Merrifield, A. , 2013. The urban question under planetary urbanization. International Journal of Urban and Regional Research . 37, 909-922.

Miraftab, F. , 2007. Governing post-apartheid spatiality: implementing City Improvement Districts in Cape Town. Antipode . 39, 602-626.

Mitchell, D. , Heynen, N. , 2009. The geography of survival and the right to the city: speculations on surveillance, legal innovation, and the criminalization of intervention. Urban Geography . 30, 611-632.

Mokonyama, M. , Mubiwa, B. , 2014. Transport in the shaping of space, in: Harrison, P. , Gotz, G. , Todes, A. , Wray, C. (Eds.), Changing Space, Changing City: Johannesburg After Apartheid . Witwatersrand University Press. Johannesburg, pp. 194-214.

Morris, A. , 1997. Physical decline in an inner-city neighbourhood. Urban Forum . 8, 153-175. Morris, A. , 1999a. Bleakness \& Light: Inner-City Transition in Hillbrow, Johannesburg . Wits University Press. Johannesburg.

Morris, A. , 1999b. Tenant-landlord relations, the anti-apartheid struggle and physical decline in Hillbrow, an inner-city neighbourhood in Johannesburg. Urban Studies . 36, 509-526.

Morris, A. , 1999c. Race relations and racism in a racially diverse inner city neighbourhood: a case study of Hillbrow, Johannesburg. Journal of Southern African Studies . 25, 667-694.

Mosoetsa, S. , 2011. Eating from One Pot: The Dynamics of Survival in Poor South African Households . Eurospan. Johannesburg.

Mosselson, A. , 2017. 'Joburg has its own momentum': towards a vernacular theorisation of urban change. Urban Studies . 54, 1280-1296.

Murray, M.J. , 2008. Taming the Disorderly City: The Spatial Landscape of Johannesburg After Apartheid . Cornell University Press. Ithaca, New York.

Murray, M.J. , 2011. City of Extremes: The Spatial Politics of Johannesburg . Duke University Press. Durham, North Carolina.

Mushongera, D. , 2017. Beyond GDP in assessing development in South Africa: the Gauteng City-Region Socio-Economic Barometer. Development Southern Africa . 34, 330-346.

Mushongera, D. , Zikhali, P. , Ngwenya, P. , 2017. A Multidimensional Poverty Index for Gauteng Province, South Africa: evidence from Quality of Life Survey Data. Social Indicators Research . 130, 277-303. 
Myers, G.A. , 2011. African Cities: Alternative Visions of Urban Theory and Practice . Zed Books. London.

Naidoo, P. , 2007. Struggles around the commodification of daily life in South Africa. Revue of African Political Economy. 34, 57-66.

Nevin, A. , 2014. Instant mutuality: the development of Maboneng in inner-city Johannesburg. Anthropology Southern Africa . 37, 187-201.

Nuttall, S. , 2004. City forms and writing the 'now' in South Africa. Journal of Southern African Studies . 30, 731-748.

Oldfield, S. , Greyling, S. , 2015. Waiting for the state: a politics of housing in South Africa. Environment and Planning A . 47, 1100-1112.

Paasche, T.F. , Yarwood, R. , Sidaway, J.D. , 2014. Territorial tactics: the socio-spatial significance of private policing strategies in Cape Town. Urban Studies . 51, 1559-1575.

Parnell, S. , Robinson, J. , 2006. Development and urban policy: Johannesburg's city development strategy. Urban Studies . 43, 337-355.

Parnell, S. , Robinson, J. , 2012. (Re)theorizing cities from the Global South: looking beyond neoliberalism. Urban Geography . 33, 593-617.

Peck, J. , 2015. Cities beyond compare? Regional Studies . 49, 160-182.

Peyroux, E. , 2006. City Improvement Districts (CIDs) in Johannesburg: assessing the political and socio-spatial implications of private-led urban regeneration. Trialog . 89, 9-14.

Peyroux, E. , 2012. Legitimating Business Improvement Districts in Johannesburg: a discursive perspective on urban regeneration and policy transfer. European Urban and Regional Studies . 19, 181-194.

Pieterse, E. , 2011. Grasping the unknowable: coming to grips with African urbanisms. Social Dynamics . 37, 5-23.

Plissart, M.F. , De Boeck, F. , 2006. Kinshasa: Tales of the Invisible City . Ludion. New York. Popke, J.E. , Ballard, R. , 2004. Dislocating modernity: identity, space and representations of street trade in Durban, South Africa. Geoforum . 35, 99-110.

Prabhala, A. , 2008, Yeoville confidential, in: Nuttall, S. , Mbembe, A. (Eds.), Johannesburg: The Elusive Metropolis . Duke University Press. Durham, North Carolina, pp. 307-316.

Prigge, W. , 2008. Reading the urban revolution: space and representation, in: Goonewardena, K. , Kipfer, S. , Milgrom, R. , Schmid, C. (Eds.), Space, Difference, Everyday Life: Reading Henri Lefebvre. Routledge. New York, pp. 46-61.

Propertuity , 2013. The Maboneng Precinct Property Growth Report 2013 . Propertuity. Johannesburg.

Rérat, P. , Lees, L. , 2011. Spatial capital, gentrification and mobility: evidence from Swiss core cities. Transactions of the Institute of British Geographers . 36, 126-142.

Robinson, J. , 1996. The Power of Apartheid: State, Power, and Space in South African Cities . Butterworth-Heinemann. Michigan.

Robinson, J. , 2006. Ordinary Cities: Between Modernity and Development . Routledge. London.

Robinson, J. , 2015. 'Arriving at' urban policies: the topological spaces of urban policy mobility. International Journal of Urban and Regional Research . 39, 831-834.

Robinson, J. , 2016. Comparative urbanism: new geographies and cultures of theorizing the urban. International Journal of Urban and Regional Research . 40, 187-199.

Roy, A. , 2009. The 21st-century metropolis: new geographies of theory. Regional Studies . 43, 819-830.

Rubin, M. , Appelbaum, A. , 2016. Spatial Transformation through Transit-Oriented Development: Synthesis Report, Spatial Transformation through Transit-Oriented Development in Johannesburg Research Report Series. South African Research Chair in Spatial Analysis and City Planning. University of the Witwatersrand. Johannesburg.

Savage, M. , 2011. The lost urban sociology of Pierre Bourdieu, in: Bridge, G. , Watson, S. (Eds.), The New Blackwell Companion to the City. Wiley Blackwell. Hoboken, New Jersey, pp. 511-520.

Schmid, C. , 2008. Henri Lefebvre's theory of the production of space: towards a threedimensional dialectic, in: Goonewardena, K. , Kipfer, S. , Milgrom, R. , Schmid, C. (Eds.), Space, Difference, Everyday Life: Reading Henri Lefebvre . Routledge. New York, pp. 27-45. Seekings, J. , Nattrass, N. , 2005. Class, Race, and Inequality in South Africa . Yale University Press. London. 
SERI , 2013. Minding the Gap: An Analysis of the Supply of and Demand for Low-Income Rental Accommodation in Inner City Johannesburg. Socio-Economic Rights Institute of South Africa. Johannesburg.

Sihlongonyane, M.F. , 2015. The rhetorical devices for marketing and branding Johannesburg as a city: a critical review. Environment and Planning: Economy and Space . 47, 2134-2152.

Simone, A. , 2001. Straddling the divides: remaking associational life in the informal African city. International Journal of Urban and Regional Research . 25, 102-117.

Simone, A. , 2004a. For the City yet to Come: Changing African Life in Four Cities . Duke University Press. Durham, North Carolina.

Simone, A. , 2004b. People as infrastructure: intersecting fragments in Johannesburg. Public Culture . 16, 407-429.

Simone, A. , 2008. The politics of the possible: making urban life in Phnom Penh. Singapore Journal of Tropical Geography . 29, 186-204.

Simone, A. , 2010. A town on its knees? Economic experimentations with postcolonial urban politics in Africa and Southeast Asia. Theory, Culture and Society . 27, 130-154.

Smith, N. , 2002. New globalism, new urbanism: gentrification as global urban strategy.

Antipode . 34, 427-450.

Stanek, L. , 2011. Henri Lefebvre on Space: Architecture, Urban Research, and the Production of Theory. University of Minnesota Press. Minnesota.

Steck, J.-F. , Didier, S. , Morange, M. , Rubin, M. , 2013. Informality, public space and urban governance: an approach through street trading (Abidjan, Cape Town, Johannesburg, Lome and Nairobi), in: Bekker, S. , Fourchard, L. (Eds.), Governing Cities in Africa: Politics and Policies . HSRC Press. Cape Town, pp. 145-168.

Stoler, A.L. , 2008. Imperial debris: reflections on ruins and ruination. Cultural Anthropology . 23, 191-219.

Teppo, A. , Millstein, M. , 2015. The place of gentrification in Cape Town, in: Lees, L. , Shin, H.B. , Lopes-Morales, E. (Eds.), Global Gentrifications: Uneven Development and Displacement . Policy Press. Bristol, pp. 419-440.

Tissington, K. , 2009. The Business of Survival: Informal Traders in Inner City Johannesburg . Centre for Applied Legal Studies. Johannesburg.

Todes, A. , 2014. The impact of policy and strategic spatial planning, in: Harrison, P. , Gotz, G. , Todes, A. , Wray, C. (Eds.), Changing Space, Changing City: Johannesburg After Apartheid . Wits University Press. Johannesburg, pp. 83-100.

Tomlinson, R. , Beauregard, R.A. , Bremner, L. , Mangcu, X. , 2003. Introduction, in: Tomlinson, R. , Beauregard, R.A. , Bremner, L. , Mangcu, X. (Eds.), Emerging Johannesburg: Perspectives on the Postapartheid City. Routledge. New York, pp. ix-xv.

van Holdt, K. , 2010. The South African post-apartheid bureaucracy: inner workings, contradictory rationales and the developmental state, in: Edigheji, O. (Ed.), Constructing a Democratic Developmental State in South Africa: Potentials and Challenges . HSRC Press. Cape Town, pp. 241-260.

van Holdt, K. , 2012a. Bodies of defiance, in: Burawoy, M. , van Holdt, K. (Eds.), Conversations with Bourdieu. Wits University Press. Johannesburg, pp. 46-50.

van Holdt, K. , 2012b. The Johannesburg moment, in: Burawoy, M. , van Holdt, K. (Eds.), Conversations with Bourdieu . Wits University Press. Johannesburg, pp. 1-6.

van Holdt, K. , 2013. The violence of order, orders of violence: between Fanon and Bourdieu. Current Sociology . 61, 112-131.

van Onselen, C. , 2001. New Babylon New Nineveh . Jonathan Ball Publishers. Johannesburg. Vicario, L. , Martinez Monje, P.M. , 2005. Another 'Guggenheim effect'? Central city projects and gentrification in Bilbao, in: Atkinson, R. , Bridge, G. (Eds.), Gentrification in Global Context: The New Urban Colonialism . Routledge. London, pp. 151-167.

Viruly, F. , Bertoldi, A. , Booth, K. , Gardner, D. , Hague, K. , 2010. Analysis of the Impact of the JDA's Area-Based Regeneration Projects on Private Sector Investments: An Overview.

Johannesburg Development Agency. Johannesburg.

Walsh, S. , 2013. We won't move: the suburbs take back the centre in urban Johannesburg. City . 17, 400-408.

Wilhelm-Solomon, M. , 2016. Decoding dispossession: eviction and urban regeneration in Johannesburg's dark buildings. Singapore Journal of Tropical Geography . 37, 378-395. 
Winkler, T. , 2009. Prolonging the global age of gentrification: Johannesburg's regeneration policies. Planning Theory . 8, 362-381.

Zack, T. , 2016. Platform to an Arrival City: Johannesburg's Park Station and Surrounds, Spatiat Transformation through Transit-Oriented Development in Johannesburg Research Report Series. South African Research Chair in Spatial Analysis and City Planning. University of the Witwatersrand. Johannesburg

Zukin, S. , 1998. Urban lifestyles: diversity and standardisation in spaces of consumption. Urban Studies . 35, 825-839.

\section{An overburdened process}

Appadurai, A. , 2000. Spectral housing and urban cleansing: notes on millennial Mumbai. Public Culture . 12, 627-651.

Ballard, R. , Rubin, M. , 2017. A 'Marshall Plan' for human settlements: how megaprojects became South Africa's housing policy. Transformation: Critical Perspectives on Southern Africa .95, 1-31.

Beall, J. , Crankshaw, O. , Parnell, S. , 2002. Uniting a Divided City: Governance and Social Exclusion in Johannesburg. Earthscan. London.

Bernt, M. , 2012. The 'double movements' of neighbourhood change: gentrification and public policy in Harlem and Prenzlauer Berg. Urban Studies . 49, 3045-3062.

Bourdieu, P. , 1990. The Logic of Practice. Stanford University Press. Stanford, California. Bourdieu, P. , 2005. The Social Structures of the Economy. Polity Press. Cambridge.

Centre for Affordable Housing Finance in Africa , 2015. Understanding the Challenges in South Africa's Gap Housing Market and Opportunities for the RDP Resale Market . Centre for Affordable Housing Finance in Africa. Johannesburg.

Charlton, S. , 2009. Housing for the nation, the city and the household: competing rationalities as a constraint to reform? Development Southern Africa . 26, 301-315.

Charlton, S. , 2014. Public housing in Johannesburg, in: Harrison, P. , Gotz, G. , Todes, A. , Wray, C. (Eds.), Changing Space, Changing City: Johannesburg After Apartheid. Wits University Press. Johannesburg, pp. 176-193.

Charlton, S. , Kihato, C. , 2006. Reaching the poor? An analysis of the influences on the evolution of South Africa's housing programme, in: Pillay, U. , Tomlinson, R. , du Toit, J. (Eds.), Democracy and Delivery: Urban Policy in South Africa. HSRC Press. Cape Town, pp. 252-282. City of Johannesburg , 2007. Inner City Regeneration Charter. City Council. Johannesburg. City of Johannesburg , 2017. City of Johannesburg Medium Term Budget 2017/18-2019/20 . City Council. Johannesburg.

COHRE , 2005. Any Room for the Poor? Forced Evictions in Johannesburg, South Africa . Centre for Housing Rights and Evictions. Johannesburg.

Colomb, C. , 2007. Unpacking new labour's 'Urban Renaissance' agenda: towards a socially sustainable reurbanization of British cities? Planning Practice and Research . 22, 1-24.

Fernandes, L. , 2004. The politics of forgetting: class politics, state power and the restructuring of urban space in India. Urban Studies . 41, 2415-2430.

Goga, S. , 2003. Property investors and decentralization: a case of false competition? in: Tomlinson, R. , Beauregard, R.A. , Bremner, L. , Mangcu, X. (Eds.), Emerging Johannesburg: Perspectives on the Postapartheid City . Routledge. New York, pp. 71-84.

HDA , 2013. Reviving Our Inner Cities: Social Housing and Urban Regeneration in South Africa . Housing Development Agency. Johannesburg, South Africa.

Hart, G. , 2002. Disabling Globilization: Places of Power in Post-Apartheid South Africa . University of California Press. Berkley and Los Angeles, California.

Harvey, D. , 2006. The Limits to Capital . Verso. London.

Harvey, D. , 2012. Rebel Cities: From the Right to the City to the Urban Revolution . Verso. London.

Huchzermeyer, M. , 2001. Housing for the poor? Negotiated housing policy in South Africa. Habitat International . 25, 303-331. 
Huchzermeyer, M. , 2003. Addressing segregation through housing policy and finance, in: Harrison, P. , Huchzermeyer, M. , Mayekiso, M. (Eds.), Confronting Fragmentation: Housing and Urban Development in a Democratic Society. University of Cape Town Press. Cape Town, pp. 211-227.

Huchzermeyer, M. , 2014. Changing housing policy in South Africa, in: Bredenoord, J. , Van Lindert, P. , Smets, P. (Eds.), Affordable Housing in the Urban Global South: Seeking

Sustainable Solutions . Routledge. London, pp. 336-348.

Klaaren, J. , Ramji, J. , 2001. Inside illegality: migration policing in South Africa after apartheid. Africa Today . 48, 34-47.

Lemanski, C. , 2014. Hybrid gentrification in South Africa: theorising across southern and northern cities. Urban Studies . 51(14), 2943-2960.

Lipietz, B. , 2008. Building a vision for the post-apartheid city: what role for participation in Johannesburg's city development strategy. International Journal of Urban and Regional Research . 32, 135-163.

Lopez-Morales, E. , 2011. Gentrification by ground rent dispossession: the shadows cast by large-scale urban renewal in Santiago de Chile. International Journal of Urban and Regional Research . 35, 330-357.

MacLeod, G. , 2002. From urban entrepreneurialism to a 'revanchist city'? On the spatial injustices of Glasgow's renaissance. Antipode . 34, 602-624.

Maloutas, T. , 2012. Contextual diversity in gentrification research. Critical Sociology . 38, 33-48.

McMichael, C. , 2015. Urban pacification and 'blitzes' in contemporary Johannesburg. Antipode 47, 1261-1278.

Miraftab, F. , 2007. Governing post-apartheid spatiality: implementing City Improvement Districts in Cape Town. Antipode . 39, 602-626.

Morange, M. , Didier, S. , 2006. Security discourses, community participation and the power structure in Cape Town, 2000-2006. Urban Forum . 17, 353-379.

Morris, A. , 1999. Bleakness \& Light: Inner-City Transition in Hillbrow, Johannesburg. Wits University Press. Johannesburg.

Murray, M.J. , 2008. Taming the Disorderly City: The Spatial Landscape of Johannesburg After Apartheid . Cornell University Press. Ithaca, New York.

Murray, M.J. , 2011. City of Extremes: The Spatial Politics of Johannesburg . Duke University Press. Durham, North Carolina.

National Department of Housing , 2004. 'Breaking New Ground.' A Comprehensive Plan for the Development of Sustainable Human Settlements.

Oelofse, M. , 2003. Social justice, social integration and the compact city: lessons from the inner city of Johannesburg, in: Harrison, P. , Huchzermeyer, M. , Mayekiso, M. (Eds.), Confronting Fragmentation: Housing and Urban Development in a Democratic Society . University of Cape Town Press. Cape Town, pp. 88-105.

Oldfield, S. , Greyling, S. , 2015. Waiting for the state: a politics of housing in South Africa. Environment and Planning A . 47, 1100-1112.

Paasche, T.F. , Yarwood, R. , Sidaway, J.D. , 2014. Territorial tactics: the socio-spatial significance of private policing strategies in Cape Town. Urban Studies . 51, 1559-1575. Pillay, A. , Naudé, W.A. , 2006. Financing low-income housing in South Africa: borrower experiences and perceptions of banks. Habitat International . 30, 872-885.

Reed-Danahay, D. , 2005. Locating Bourdieu . Indiana University Press. Bloomington, Indiana. Saborio, S. , 2013. The pacification of the favelas: mega events, global competitiveness, and the neutralization of marginality. Socialist Studies . 9, 130-145.

Schinkel, W. , van den Berg, M. , 2011. City of exception: the Dutch revanchist city and the urban homo sacer. Antipode. 43, 1911-1938.

SERI , 2016. Edged Out: Spatial Mismatch and Spatial Justice in South Africa's Main Urban Areas . Socio-Economic Rights Institute of South Africa. Johannesburg.

Smets, P. , 1999. Housing finance trapped in a dilemma of perceptions: affordability criteria for the urban poor in India questioned. Housing Studies . 14, 821-838.

Smets, P. , 2004. Housing Finance and the Urban Poor . Rawat Publications. Jaipur. Smith, N. , 1987. Gentrification and the rent gap. Annals of the Association of American Geographers . 77, 462-465. 
Smith, N. , 1996. The New Urban Frontier: Gentrification and the Revanchist City. Routledge. London.

Smith, N. , 2002. New globalism, new urbanism: gentrification as global urban strategy. Antipode. 34, 427-450.

South African Revenue Service Legal and Policy Division , 2006. Guide to the Urban Development Zone Tax Incentive. South African Revenue Service. Pretoria.

Statistics South Africa, 2012. Census 2011 Statistical Release (No. PO301.4) . Statistics South Africa. Pretoria, South Africa.

Swanson, K. , 2007. Revanchist urbanism heads south: the regulation of indigenous beggars and street vendors in Ecuador. Antipode . 39, 708-728.

Teppo, A. , Millstein, M. , 2015. The place of gentrification in Cape Town, in: Lees, L. , Shin, H.B. , Lopes-Morales, E. (Eds.), Global Gentrifications: Uneven Development and Displacement . Policy Press. Bristol, pp. 419-440.

Tissington, K. , 2011. A Resource Guide to Housing in South Africa 1994-2010: Legislation, Policy, Programmes and Practice. Socio-Economic Rights Institute of South Africa.

Johannesburg.

Tomlinson, M. , 2006. From 'quantity' to 'quality': restructuring South Africa's housing policy ten years after. International Development and Planning Revue . 28, 85-104.

Tomlinson, R. , Beauregard, R.A. , Bremner, L., Mangcu, X. , 2003. The postapatheid struggle for an integrated Johannesburg, in: Tomlinson, R. , Beauregard, R.A. , Bremner, L. , Mangcu, X. (Eds.), Emerging Johannesburg: Perspectives on the Postapartheid City . Routledge. New York, pp. 3-20.

Turok, I. , Robson, B. , 2007. Linking neighbourhood regeneration to city-region growth: why and how? Journal of Urban Regeneration and Renewal . 1, 44-54.

van Holt, K. , Langa, M. , Molapo, S. , Mogapi, N. , Ngubeni, K. , Dlamini, J. , Kirsten, A. , 2011. The Smoke that Calls: Insurgent Citizenship, Collective Violence and the Struggle for a Place in the New South Africa. Eight Case Studies of Community Protest and Xenophobic Violence . Centre for the Study of Violence and Reconciliation and Society, Work and Development Institute, University of the Witwatersrand. Johannesburg.

Viruly, F. , Bertoldi, A. , Booth, K. , Gardner, D. , Hague, K. , 2010. Analysis of the Impact of the JDA's Area-Based Regeneration Projects on Private Sector Investments: An Overview.

Johannesburg Development Agency. Johannesburg.

Winkler, T. , 2009. Prolonging the global age of gentrification: Johannesburg's regeneration policies. Planning Theory . 8, 362-381.

Zack, T. , Bertoldi, A. , Charlton, S. , Kihato, M. , Silverman, M. , 2009. Draft Strategy for Addressing Blighted Medium and High Density Residential 'Bad Buildings' in Johannesburg: Working Document for Discussion . City of Johannesburg. Johannesburg.

\section{The contradictory praxis of regeneration}

Alvesson, M. , Sköldberg, K. , 2009. Reflexive Methodology: New Vistas for Qualitative Research. SAGE. California.

Bennett, T. , Savage, M. , Silva, E.B. , Warde, A. , Gayo-Cal, M. , Wright, D. , 2009. Culture, Class, Distinction. Routledge. New York.

Benson, M. , Jackson, E. , 2013. Place-making and place maintenance: performativity, place and belonging among the middle classes. Sociology . 47, 793-809.

Bourdieu, P. , 1984. Distinction: A Social Critique of the Judgement of Taste. Harvard University Press. Cambridge, Massachusetts.

Bourdieu, P. , 1986. The forms of captial, in: Richardson, J.G. (Ed.), Handbook of Theory and Research for the Sociology of Education . Greenwood. Westport, Connecticut, pp. 241-258. Bourdieu, P. , 1990. The Logic of Practice. Stanford University Press. Stanford, California. Bourdieu, P. , 1998. Practical Reason: On the Theory of Action . Stanford University Press. Stanford, California.

Bourdieu, P. , 2005. The Social Structures of the Economy. Polity Press. Cambridge.

Bourdieu, P. , Passeron, J.-C. , 1990. Reproduction in Education, Society and Culture. SAGE. California. 
Bremner, L. , 2000. Reinventing the Johannesburg inner city. Cities . 17, 185-193.

Burawoy, M. , 2012. Theory and practice: Marx meets Bourdieu, in: Burawoy, M. , van Holt, K. , Conversations with Bourdieu . Wits University Press. Johannesburg, pp. 31-45.

Centner, R. , 2008. Places of privileged consumption practices: spatial capital, the dot-com habitus, and San Francisco's internet boom. City and Community . 7, 193-223.

Coiacetto, E.J. , 2000. Places shape place shapers? Real estate developers' outlooks concerning community, planning and development differ between places. Planning Practice and Research . 15, 353-374.

Comaroff, J. , Comaroff, J.L. , 2012. Theory from the South: Or, How Euro-America Is Evolving toward Africa . Paradigm Publishers. Boulder, Colorado.

Desai, R. , 2010. The Battle for Johannesburg . Uhuru Productions. Johannesburg.

Duca, F. , 2013. New community in a new space: artificial, natural, created, contested. An idea from a golf estate in Johannesburg. Social Dynamics: A Journal of African Studies . 39(2), 191-209.

Gale, T. , Parker, S. , 2015. Calculating student aspiration: Bourdieu, spatiality and the politics of recognition. Cambridge Journal of Education . 45, 81-96.

Gaule, S. , 2005. Alternating currents of power: from colonial to post-apartheid spatial patterns in Newtown, Johannesburg. Urban Studies . 42, 2335-2361.

Hall, S.M. , 2015. Super-diverse street: a 'trans-ethnography' across migrant localities. Ethnic and Racial Studies . 38, 22-37.

Hassim, S. , Kupe, T. , Worby, E. (Eds.), 2008. Go Home or Die Here: Violence, Xenophobia and the Reinvention of Difference in South Africa. Wits University Press. Johannesburg, South Africa.

Hou, J. , 2010. Insurgent Public Space: Guerrilla Urbanism and the Remaking of Contemporary Cities . Taylor \& Francis. Abingdon.

Isin, E.F. , 2008. The city as the site of the social, in: Isin, E.F. (Ed.), Recasting the Social in Citizenship. University of Toronto Press. Toronto, pp. 261-280.

Jackson, E. , Benson, M. , 2014. Neither 'deepest, darkest Peckham' nor 'run-of-the-mill' East Dulwich: the middle classes and their 'others' in an Inner-London neighbourhood. International Journal of Urban and Regional Research . 38, 1195-1210.

Kriese, U. , Scholz, R.W. , 2012. Lifestyle ideas of house builders and housing investors. Housing Theory and Society . 29, 288-320.

Ley, D. , 2003. Artists, aestheticisation and the field of gentrification. Urban Studies . 40, 2527-2544.

Lingard, B. , Sellar, S. , Baroutsis, A. , 2015. Researching the habitus of global policy actors in education. Cambridge Journal of Education . 45, 25-42.

Misago, J.P. , Monson, T. , Polzer, T. , Landau, L.B. , 2010. May 2008 Violence against Foreign Nationals in South Africa: Understanding Causes and Evaluating Responses . Consortium for Refugees and Migrants in South Africa and Forced Migration Studies Programme.

Johannesburg.

Mosselson, A. , 2017. 'Joburg has its own momentum': towards a vernacular theorisation of urban change. Urban Studies . 54(5), 1280-1296.

Murray, M.J. , 2008. Taming the Disorderly City: The Spatial Landscape of Johannesburg After Apartheid . Cornell University Press. Ithaca, New York.

Murray, M.J. , 2011. City of Extremes: The Spatial Politics of Johannesburg . Duke University Press. Durham, North Carolina.

Neocosmos, M. , 2010. From 'Foreign Natives' to 'Native Foreigners': Explaining Xenophobia in Post-Apartheid South Africa: Citizenship and Nationalism, Identity and Politics . African Books Collective. Oxford.

Nevin, A. , 2014. Instant mutuality: the development of Maboneng in inner-city Johannesburg. Anthropology South Africa . 37, 187-201.

Ong, A. , 2011. Worlding cities, or the art of being global, in: Roy, A. , Ong, A. (Eds.), Worlding Cities: Asian Experiments and the Art of Being Global. Blackwell Publishing. Chichester, Sussex, pp. 1-26.

Reay, D. , 2004. 'It's all becoming habitus': beyond the habitual uses of habitus in educational research. British Journal of Sociology of Education . 24, 431-444.

Reay, D. , 2015. Habitus and the psychosocial: Bourdieu with feelings. Cambridge Journal of Education . 45, 9-23. 
Schmid, C. , 2008. Henri Lefebvre's theory of the production of space: towards a threedimensional dialectic, in: Goondewardena, K. , Kipfer, S. , Milgrom, R. , Schmid, C. , (Eds.), Space, Difference, Everyday Life: Reading Henri Lefebvre. Routledge. New York, pp. 27-45. Sihlongonyane, M.F. , 2015. The rhetorical devices for marketing and branding Johannesburg as a city: a critical review. Environment and Planning: Economy and Space . 47, 2134-2152. Simone, A.M. , 2004. People as infrastructure: intersecting fragments in Johannesburg. Public Culture . 16, 407-429.

Smith, N. , 1996. The New Urban Frontier: Gentrification and the Revanchist City . Routledge. New York.

Viruly, F. , Bertoldi, A. , Booth, K. , Gardner, D. , Hague, K. , 2010. Analysis of the Impact of the JDA's Area-Based Regeneration Projects on Private Sector Investments: An Overview . Johannesburg Development Agency. Johannesburg.

Wacquant, L. , 2011. Habitus as topic and tool: reflections on becoming a prizefighter. Qualitative Research in Psychology . 8, 81-92.

Walsh, S. , 2013. 'We won't move': the suburbs take back the centre in urban Johannesburg. City . 17, 400-408.

Watt, P. , 2009. Living in an oasis: middle-class disaffiliation and selective belonging in an English suburb. Environment and Planning: Economy and Space . 41, 2874-2892.

Winkler, T. , 2009. Prolonging the global age of gentrification: Johannesburg's regeneration policies. Planning Theory . 8, 362-381.

Zheng, J. , 2013. Creating urban images through global flows: Hong Kong real estate developers in Shanghai's urban redevelopment. City, Culture and Society . 4, 65-76.

\section{Urban management and security}

Adey, P. , 2014. Security atmospheres or the crystallisation of worlds. Environment and Planning: Society and Space. 32, 834-851.

Adey, P. , Brayer, L. , Masson, D. , Murphy, P. , Simpson, P. , Tixier, N. , 2013. 'Pour votre tranquillité': ambiance, atmosphere, and surveillance. Geoforum . 49, 299-309.

Allen, J. , 2006. Ambient power: Berlin's Potsdamer Platz and the seductive logic of public spaces. Urban Studies . 43, 441-455.

Atkinson, R. , 2003. Domestication by cappuccino or a revenge on urban space? Control and empowerment in the management of public spaces. Urban Studies . 40, 1829-1843.

Baker, B. , 2009. Security in Post-Conflict Africa: The Role of Nonstate Policing . CRC Press. Boca Raton, Florida.

Beall, J. , Crankshaw, O. , Parnell, S. , 2002. Uniting a Divided City: Governance and Social Exclusion in Johannesburg . Earthscan. London.

Bénit-Gbaffou, C. , 2009. In the shadow of 2010: democracy and displacement in the Greater Ellis Park Development project, in: Pillay, U. , Tomlinson, R. , Bass, O. (Eds.), Development and Dreams: The Urban Legacy of the 2010 Football World Cup . HSRC Press. Cape Town, pp. 200-222.

Bénit-Gbaffou, C. , Dubresson, A. , Fourchard, L. , Ginisty, K. , Jaglin, S. , Olukoju, A. , Owuor, S. , Vivet, J. , 2013. Exploring the role of party politics in the governance of African cities, in: Bekker, S. , Fourchard, L. (Eds.), Governing Cities in Africa: Politics and Policies . HSRC Press. Cape Town, pp. 17-42.

Bourdieu, P. , 1984. Distinction: A Social Critique of the Judgement of Taste. Harvard University Press. Cambridge, Massachusetts.

Bremner, L. , 2000. Reinventing the Johannesburg inner city. Cities . 17, 185-193.

Brown, B. , Benedict, W.R. , 2002. Perceptions of the police: past findings, methodological issues, conceptual issues and policy implications. Policing: An International Journal . 25, 543-580.

Buur, L. , Jensen, S. , 2004. Introduction: vigilantism and the policing of everyday life in South Africa. African Studies . 63, 139-152.

Campbell, E. , 2013. Transgression, affect and performance: choreographing a politics of urban space. British Journal of Criminology . 53, 18-40. 
Chipkin, I. , 2013. Whither the state? Corruption, institutions and state-building in South Africa. Politikon . 40, 211-231.

Clarno, A. , 2013. Rescaling white space in post-apartheid Johannesburg. Antipode . 45, 1190-1212.

Clarno, A. , Murray, M.J. , 2013. Policing in Johannesburg after apartheid. Social Dynamics . 39, 210-227.

COHRE , 2005. Any Room for the Poor? Forced Evictions in Johannesburg, South Africa .

Centre for Housing Rights and Evictions. Johannesburg.

Coleman, R. , 2004. Watching the degenerate: street camera surveillance and urban regeneration. Local Economics . 19, 199-211.

Coleman, R. , Sim, J. , 2000. 'You'll never walk alone': CCTV surveillance, order and neo-liberal rule in Liverpool city centre. British Journal of Sociology . 51, 623-639.

Cook, I.R. , 2010. Policing, partnerships, and profits: the operations of Business Improvement Districts and Town Center Management Schemes in England. Urban Geography . 31, 453-478. Cooper-Knock, S.J. , 2016. Behind closed gates: everyday policing in Durban, South Africa. Africa . 86, 98-121.

Crawford, M. , 1992. The world in a shopping mall, in: Sorkin, M. (Ed.), Variations on a Theme Park: The New American City and the End of Public Space. Noonday Press. New York, pp. 3-30.

Davis, D.E. , 2010. Irregular armed forces, shifting patterns of commitment, and fragmented sovereignty in the developing world. Theory and Society. 39, 397-413.

Didier, S. , Peyroux, E. , Morange, M. , 2012. The spreading of the City Improvement District model in Johannesburg and Cape Town: urban regeneration and the neoliberal agenda in South Africa. International Journal of Urban and Regional Research . 36, 915-935.

Diphoorn, T. , 2015a. 'It's all about the body': the bodily capital of armed response officers in South Africa. Medical Anthropology . 34, 336-352.

Diphoorn, T. , 2015b. Twilight policing: private security practices in South Africa. British Journal of Criminology . 56(2), 313-331.

Diphoorn, T. , 2017. The 'Bravo Mike Syndrome': private security culture and racial profiling in South Africa. Policing and Society . 27, 525-540.

Dirsuweit, T. , 2007. Between ontological security and the right to difference: road closures, communitarianism and urban ethics in Johannesburg, South Africa. Autrepart . 42, 53-71.

Dirsuweit, T. , Wafer, A. , 2006. Scale, governance and the maintenance of privileged control: the case of road closures in Johannesburg's northern suburbs. Urban Forum . 17, 327-352.

Eick, V. , 2012. The co-production of purified space: hybrid policing in German Business Improvement Districts. European Urban and Regional Studies . 19, 121-136.

Flusty, S. , 2002. The banality of interdiction: surveillance, control and the displacement of diversity. International Journal of Urban and Regional Research . 25, 658-664.

Fourchard, L. , 2011. The politics of mobilization for security in South African townships. African Affairs . 110, 607-627.

Fyfe, N. , 2004. Zero tolerance, maximum surveillance? Deviance, difference and crime control in the late modern city, in: Lees, L. (Ed.), The Emancipatory City? Paradoxes and Possibilities . Sage Publications. London, pp. 40-56.

Garland, D. , 1996. The limits of the sovereign state. British Journal of Criminology . 36, 445-471.

Gaule, S. , 2005. Alternating currents of power: from colonial to post-apartheid spatial patterns in Newtown, Johannesburg. Urban Studies . 42, 2335-2361.

Gupta, A. , 2013. Messy bureaucracies. HAU Journal of Ethnographic Theory . 3, 435-440. Hayward, K. , 2004. City Limits: Crime, Consumer Culture and the Urban Experience. Routledge. New York.

Hornberger, J. , 2004. 'My police - your police': the informal privatisation of the police in the inner city of Johannesburg. African Studies . 63, 213-230.

Jaffe, R. , 2013. The hybrid state: crime and citizenship in urban Jamaica. American Ethnologist 40, 734-748.

Kihato, C. , 2007. Governing the city? South Africa's struggle to deal with urban immigrants after apartheid. African Identities . 5, 261-278.

Koch, R. , Latham, A. , 2013. On the hard work of domesticating a public space. Urban Studies . $50,6-21$. 
Koskela, H. , 2000. 'The gaze without eyes': video-surveillance and the changing nature of urban space. Progress in Human Geography . 24, 243-265.

Landman, K. , 2006. Privatising public space in post-apartheid South African cities through neighbourhood enclosures. GeoJournal . 66, 133-146.

Langegger, S. , Koester, S. , 2016. Dwelling without a home: Denver's splintered public spaces, in: De Backer, M. , Melgaço, L. , Varna, G. , Menichelli, F. (Eds.), Order and Conflict in Public Space . Routledge. London, pp. 140-159.

Lemanski, C. , 2006. Residential responses to fear (of crime plus) in two Cape Town suburbs: implications for the post-apartheid city. Journal of International Development . 18, 787-802.

Lemanski, C. , Oldfield, S. , 2009. The parallel claims of gated communities and land invasions in a Southern city: polarised state responses. Environment and Planning A . 41, 634-648.

Lippert, R. , 2012. 'Clean and safe' passage: Business Improvement Districts, urban security modes, and knowledge brokers. European Urban and Regional Studies . 19, 167-180.

Loader, I. , 1999. Consumer culture and the commodification of policing and security. Sociology . 33, 373-392.

MacLeod, G. , 2002. From urban entrepreneurialism to a 'revanchist city'? On the spatial injustices of Glasgow's renaissance. Antipode . 34, 602-624.

Marks, M. , 2005. Transforming the Robocops . UKZN Press. Scotsville, South Africa.

Mayson, S.S., Charlton, S. , 2015. Accommodation and tenuous livelihoods in Johannesburg's inner city: the 'rooms' and 'spaces' typologies. Urban Forum . 26, 343-372.

McMichael, C. , 2015. Urban pacification and 'blitzes' in contemporary Johannesburg. Antipode 47, 1261-1278.

Mendes, A.F. , 2014. Between shocks and finance: pacification and the integration of the favela into the city in Rio de Janeiro. South Atlantic Quarterly . 113, 866-873.

Miraftab, F. , 2007. Governing post apartheid spatiality: implementing City Improvement Districts in Cape Town. Antipode. 39, 602-626.

Mkhize, T. , Forthcoming. Urban Crime and Grime: Lessons from Hillbrow's eKhaya Residential City Improvement District, Urban Innovations. Studying and Documenting Innovative

Approaches to Urban Pressures. Department of Planning Monitoring and Evaluation.

Morris, A. , 1999a. Bleakness \& Light: Inner-City Transition in Hillbrow, Johannesburg . Wits University Press. Johannesburg.

Morris, A. , 1999b. Tenant-landlord relations, the anti-apartheid struggle and physical decline in Hillbrow, an inner-city neighbourhood in Johannesburg. Urban Studies . 36, 509-526.

Mosselson, A. , 2017. 'It's not a place I like, but I can live with it': ambiguous experiences of living in state-subsidised rental housing in inner-city Johannesburg. Transformation: Critical Perspectives on Southern Africa . 93, 142-169.

Murray, M.J. , 2008. Taming the Disorderly City: The Spatial Landscape of Johannesburg After Apartheid . Cornell University Press. Ithaca, New York.

Murray, M.J. , 2011. City of Extremes: The Spatial Politics of Johannesburg . Duke University Press. Durham, North Carolina.

Myers, G.A. , 2011. African Cities: Alternative Visions of Urban Theory and Practice . Zed Books. London.

Németh, J. , 2006. Conflict, exclusion, relocation: skateboarding and public space. Journal of Urban Design . 11, 297-318.

Norris, C. , Moran, J. , Armstrong, G. , 1998. Surveillance, Closed Circuit Television, and Social Control . Ashgate. Farnham.

Paasche, T.F. , Yarwood, R. , Sidaway, J.D. , 2014. Territorial tactics: the socio-spatial significance of private policing strategies in Cape Town. Urban Studies . 51, 1559-1575.

Parnell, S. , Robinson, J. , 2012. (Re)theorizing cities from the Global South: looking beyond neoliberalism. Urban Geography. 33, 593-617.

Peyroux, E. , 2012. Legitimating Business Improvement Districts in Johannesburg: a discursive perspective on urban regeneration and policy transfer. European Urban and Regional Studies . 19, 181-194.

Pow, C.P. , 2015. Urban dystopia and epistemologies of hope. Progress in Human Geography . 39, 464-485.

Saborio, S. , 2013. The pacification of the favelas: mega events, global competitiveness, and the neutralization of marginality. Socialist Studies . 9, 130-145. 
Sampson, R.J. , Raudenbush, S.W. , 2004. Seeing disorder: neighborhood stigma and the social construction of 'broken windows.' Social Psychology Quarterly . 67, 319-342.

Schinkel, W. , van Den Berg, M. , 2011. City of exception: the Dutch revanchist city and the urban homo sacer. Antipode . 43, 1911-1938.

Schuermans, N. , Spoctor, M. , 2016. Avoiding encounters with poverty: aesthetics, politics and economics in a privaleged neighbourhood of Cape Town, in: De Backer, M. , Melgaço, L. , Varna, G. , Menichelli, F. (Eds.), Order and Conflict in Public Space . Routledge. London, pp. 79-100.

Smith, N. , 1996. The New Urban Frontier: Gentrification and the Revanchist City . Routledge. New York.

Staeheli, L.A. , 2008. Citizenship and the problem of community. Political Geography . 27, 5-21. Steinberg, J. , 2008. Thin Blue: The Unwritten Rules of Policing South Africa . Jonathan Ball with Open Society Foundation for South Africa. Johannesburg.

Stewart, K. , 2011. Atmospheric attunements. Environment and Planning: Society and Space . 29, 445-453.

Super, G. , 2015. Violence and democracy in Khayelitsha: governing crime through the 'Community.' Stability: International Journal of Security and Development . 4, 1-20.

Super, G. , 2016. Volatile sovereignty: governing crime through the community in Khayelitsha. Law and Society Revue. 50, 450-483.

Swanson, K. , 2007. Revanchist urbanism heads south: the regulation of indigenous beggars and street vendors in Ecuador. Antipode. 39, 708-728.

Vigneswaran, D. , 2014. The contours of disorder: crime maps and territorial policing in South Africa. Environment and Planning: Society and Space . 32, 91-107.

Viruly, F. , Bertoldi, A. , Booth, K. , Gardner, D. , Hague, K. , 2010. Analysis of the Impact of the JDA's Area-Based Regeneration Projects on Private Sector Investments: An Overview . Johannesburg Development Agency. Johannesburg.

Weitzer, R. , Tuch, S.A. , 2005. Determinants of public satisfaction with the police. Policing Quarterly . 8, 279-297.

Winkler, T. , 2008. Reimagining inner-city regeneration in Hillbrow, Johannesburg: identifying a role for faith-based community development, in: Harper, T.L. , Gar-On Yeh, A. , Costa, H. (Eds.), Dialogues in Urban and Regional Planning . Routledge. New York, pp. 133-149. Zukin, S. , 1995. The Cultures of Cities . Wiley. Hoboken, New Jersey.

\section{Ambiguous experiences of regeneration}

Alexander, P. , 2010. Rebellion of the poor: South Africa's service delivery protests - a preliminary analysis. Revue of African Political Economy . 37, 25-40.

Allen, K. , Hollingworth, S. , 2013. 'Sticky subjects' or 'cosmopolitan creatives'? Social class, place and urban young people's aspirations for work in the knowledge economy. Urban Studies . 50, 499-517.

Appadurai, A. , 2001. Deep democracy: urban governmentality and the horizon of politics. Environment and Urbanization . 13, 23-43.

Benson, M. , Jackson, E. , 2013. Place-making and place maintenance: performativity, place and belonging among the middle classes. Sociology . 47, 793-809.

Bhat, M.A. , Rather, T.A. , 2013. Youth transitions in Kashmir: exploring the relationships between habitus, ambitions and impediments. South Asia Research . 33, 185-204.

Bourdieu, P. , 1990. The Logic of Practice. Stanford University Press. Stanford, California. Bourdieu, P. , 2005. Habitus, in: Hillier, J. , Rooksby, E. (Eds.), Habitus: A Sense of Place . Ashgate Publishing. Farnham, pp. 43-49.

Bourdieu, P. , Passeron, J.C. , 1990. Reproduction in Education, Society and Culture . SAGE. California.

Butler, T. , Robson, G. , 2003. Negotiating their way in: the middle classes, gentrification and the deployment of capital in a globalising metropolis. Urban Studies . 40, 1791-1809.

Centner, R. , 2008. Places of privileged consumption practices: spatial capital, the dot-com habitus, and San Francisco's internet boom. City and Community . 7, 193-223. 
Desai, A. , 2002. We Are the Poors: Community Struggles in Post-Apartheid South Africa . Monthly Review Press. New York.

Dlamini, J. , 2009. Native Nostalgia . Jacana Media. Auckland Park, South Africa.

Gale, F. , 2005.The endurance of Aboriginal women in Australia, in: Hillier, J., Rooksby, E. (Eds.), Habitus: A Sense of Place. Ashgate Publishing. Farnham, pp. 356-370.

Gale, T. , Parker, S. , 2015. Calculating student aspiration: Bourdieu, spatiality and the politics of recognition. Cambridge Journal of Education . 45, 81-96.

Gevisser, M. , 2008. From the ruins, in: Nuttall, S. , Mbembe, A. (Eds.), Johannesburg: The Elusive Metropolis . Duke University Press. Durham, North Carolina, pp. 317-336.

Gevisser, M. , 2014. Lost and Found in Johannesburg. Farrar Straus Giroux. New York. Gotz, G. , Todes, A. , 2014. Johannesburg's urban space economy, in: Harrison, P. , Gotz, G. , Todes, A. , Wray, C. (Eds.), Changing Space, Changing City: Johannesburg After Apartheid . Wits University Press. Johannesburg, pp. 117-136.

Hillier, J. , Rooksby, E. , 2005. Introduction to first edition, in: Hillier, J. , Rooksby, E. (Eds.), Habitus: A Sense of Place. Ashgate Publishing. Farnham, pp. 19-42.

Holt, L. , 2008. Embodied social capital and geographic perspectives: performing the habitus. Progress in Human Geography. 32, 227-246.

Huchzermeyer, M. , 2011. Tenement Cities: From 19th Century Berlin to 21st Century Nairobi . Africa World Press. Trenton, New Jersey.

JHC , n.d. Tenant profile - inner-city of JHB: an overview 2006-2012. (Unpublished.)

Johannesburg Housing Company.

Kihato, C. , 2013. Migrant Women of Johannesburg: Everyday Life in an In-Between City .

Palgrave Macmillan. New York.

Kihato, C.W. , 2014. Lost dreams? Tales of the South African city twenty years after apartheid. African Identities . 12, 357-370.

Landau, L.B. , 2006. Transplants and transients: idioms of belonging and dislocation in innercity Johannesburg. African Studies Review . 49, 125-145.

Landau, L.B. , 2018. Friendship fears and communities of convenience in Africa's urban estuaries: connection as measure of urban condition. Urban Studies . 55, 505-521.

Lefebvre, H. , 1991. The Production of Space. Blackwell Publishers. Oxford.

Malcomess, B. , Wilhelm-Solomon, M. , 2016. Valleys of salt in the house of God: religious reterritorialisation and urban space, in: Wilhelm-Solomon, M. , Nunez, L. , Kankonde Bukasa, P. , Malcomess, B. (Eds.), Routes and Rites to the City: Mobility, Diversity and Religious Space in Johannesburg . Palgrave Macmillan. London, pp. 31-60.

Mokonyama, M. , Mubiwa, B. , 2014. Transport in the shaping of space, in: Todes, A. , Wray, C. , Gotz, G. , Harrison, P. (Eds.), Changing Space, Changing City: Johannesburg After Apartheid Wits University Press. Johannesburg.

Oldfield, S. , Greyling, S. , 2015. Waiting for the state: a politics of housing in South Africa. Environment and Planning A . 47, 1100-1112.

Parnell, S. , Pieterse, E. , 2010. The 'right to the city': institutional imperatives of a developmental state. International Journal of Urban and Regional Research . 34, 146-162.

Prigge, W. , 2008. Reading the urban revolution: space and representation, in: Goonewardena, K. , Kipfer, S. , Milgrom, R. , Schmid, C. (Eds.), Space, Difference, Everyday Life: Reading Henri Lefebvre. Routledge. New York, pp. 46-61.

Rérat, P. , Lees, L. , 2011. Spatial capital, gentrification and mobility: evidence from Swiss core cities. Transactions of the Institute of British Geographers . 36, 126-142.

Sen, A. , 2001. Development as Freedom . Oxford Paperbacks. Oxford.

Simone, A. , 2008. The politics of the possible: making urban life in Phnom Penh. Singapore Journal of Tropical Geography . 29, 186-204.

Stanek, Ł. , 2008. Space as concrete abstraction: Hegel, Marx, and modern urbanism in Henri Lefebvre, in: Goonewardena, K. , Kipfer, S. , Milgrom, R. , Schmid, C. (Eds.), Space, Difference, Everyday Life: Reading Henri Lefebvre. Routledge. New York, pp. 62-79.

Stanek, Ł. , 2011. Henri Lefebvre on Space: Architecture, Urban Research, and the Production of Theory. University of Minnesota Press. Minneapolis, Minnesota.

Thrift, N. , 2005. But malice aforethought: cities and the natural history of hatred. Transactions of the Institute of British Geographers . 30, 133-150.

Winkler, T. , 2008. Reimagining inner-city regeneration in Hillbrow, Johannesburg: identifying a role for faith-based community development, in: Harper, T.L. , Gar-On Yeh, A. , Costa, H. 
(Eds.), Dialogues in Urban and Regional Planning . Routledge. New York, pp. 133-149.

Zipin, L. , Sellar, S. , Brennan, M. , Gale, T. , 2015. Educating for futures in marginalized regions: a sociological framework for rethinking and researching aspirations. Education Philosophy and Theory . 47, 227-246.

\section{The space that regeneration makes}

Ally, S. , 2011. Domestics, 'dirty work' and the affects of domination. South African Revue of Sociology . 42, 1-7.

Back, L. , 2015. Why everyday life matters: class, community and making life livable. Sociology . 49, 820-836.

Beavon, K.S.O. , 2004. Johannesburg: The Making and Shaping of the City . University of South Africa Press. Pretoria.

Butler, T. , Robson, G. , 2001. Social capital, gentrification and neighbourhood change in London: a comparison of three South London neighbourhoods. Urban Studies . 38, 2145-2162.

Butler, T. , Robson, G. , 2003. Negotiating their way in: the middle classes, gentrification and the deployment of capital in a globalising metropolis. Urban Studies . 40, 1791-1809.

Caldeira, T.P.R. , 2000. City of Walls: Crime, Segregation, and Citizenship in São Paulo . University of California Press. Berkeley, California.

Chari, S. , 2017. The blues and the damned: (Black) life-that-survives capital and biopolitics. Critical African Studies . 9, 152-173.

Crankshaw, O. , Gilbert, A. , Morris, A. , 2000. Backyard Soweto. International Journal of Urban and Regional Research . 24, 841-857.

Delaney, D. , 2002. The space that race makes. The Professional Geographer . 54, 6-14. Erwin, K. , 2015. Race, place and identity in Kenneth Gardens: narratives from a low-cost housing estate in Durban. Urban Forum . 26, 187-201.

Fyfe, N. , 2004. Zero tolerance, maximum surveillance? Deviance, difference and crime control in the late modern city, in: Lees, L. (Ed.), The Emancipatory City? Paradoxes and Possibilities . Sage Publications. London, pp. 40-56.

Graham, S. , Marvin, S. , 2001. Splintering Urbanism: Networked Infrastructures, Technological Mobilities and the Urban Condition . Psychology Press. London.

Hall, T. , Smith, R.J. , 2015. Care and repair and the politics of urban kindness. Sociology . 49, 3-18.

Low, S. , Smith, N. (Eds.), 2006. The Politics of Public Space . Routledge. New York.

Mayson, S.S., Charlton, S. , 2015. Accommodation and tenuous livelihoods in Johannesburg's inner city: the 'rooms' and 'spaces' typologies. Urban Forum . 26, 343-372.

Mbembe, A. , Nuttall, S. , 2008. Introduction: Afropolis, in: Nuttall, S. , Mbembe, A. (Eds.), Johannesburg: The Elusive Metropolis . Duke University Press. Durham, North Carolina, pp. 1-33.

Mitchell, D. , 1995. The end of public space? People's park, definitions of the public, and democracy. Annals of the Association of American Geographers . 85, 108-133.

Morris, A. , 1999a. Tenant-landlord relations, the anti-apartheid struggle and physical decline in Hillbrow, an inner-city neighbourhood in Johannesburg. Urban Studies . 36, 509-526.

Morris, A. , 1999b. Race relations and racism in a racially diverse inner city neighbourhood: a case study of Hillbrow, Johannesburg. Journal of Southern African Studies . 25, 667-694.

Murray, M.J. , 2008. Taming the Disorderly City: The Spatial Landscape of Johannesburg After Apartheid . Cornell University Press. Ithaca, New York.

Murray, M.J. , 2011. City of Extremes: The Spatial Politics of Johannesburg . Duke University Press. Durham, North Carolina.

Naidoo, P. , 2007. Struggles around the commodification of daily life in South Africa. Revue of African Political Economy. 34, 57-66.

Ndlovu-Gatsheni, S.J. , 2013. Coloniality of Power in Postcolonial Africa . African Books Collective. Oxford.

Netswera, F.G. , Phago, K.G. , 2009. Relationship between the affordability of basic municipal services and satisfaction: the Soweto community case study. Journal of Public Administration . 


\section{4, 133-144.}

Popke, J.E. , Ballard, R. , 2004. Dislocating modernity: identity, space and representations of street trade in Durban, South Africa. Geoforum . 35, 99-110.

Purcell, M. , 2002. Excavating Lefebvre: the right to the city and its urban politics of the inhabitant. GeoJournal . 58, 99-108.

SERI and CUBES, 2013. A Tenant's Huide to Rental Housing . Socio-Economic Rights Institute of South Africa and Centre for Urbanism and Built Environment Studies, University of the Witwatersrand. Johannesburg.

Stoler, A.L. , 2008. Imperial debris: reflections on ruins and ruination. Cultural Anthropology . 23, 191-219.

Tissington, K. , Wilson, S. , 2011. SCA upholds rights of urban poor in Blue Moonlight judgement. ESR Revue: Economic and Social Rights in South Africa . 12, 3-6.

Tomlinson, R. , 1999. Ten years in the making. Urban Forum . 10, 1-39.

Wilson, S. , 2010. Breaking the tie: evictions from private land, homelessness and a new normality. South African Law Journal . 126, 270-290.

\section{Conclusion}

Aalbers, M.B. , 2012. Subprime Cities: The Political Economy of Mortgage Markets . Wiley. Hoboken, New Jersey.

Alves, J.A. , 2014. From necropolis to blackpolis: necropolitical governance and black spatial praxis in São Paulo, Brazil. Antipode . 46, 323-339.

Ballard, R. , Dittgen, R. , Harrison, P. , Todes, A. , 2017. Megaprojects and urban visions: Johannesburg's Corridors of Freedom and Modderfontein. Transformation: Critical Perspectives on Southern Africa . 95, 111-139.

Butler, T. , Lees, L. , 2006. Super-gentrification in Barnsbury, London: globalization and gentrifying global elites at the neighbourhood level. Transactions of the Institute of British Geographers . 31, 467-487.

Chakrabarty, D. , 2009. Provincializing Europe: Postcolonial Thought and Historical Difference . Princeton University Press. Princeton, New Jersey.

Chaskin, R.J. , Joseph, M.L. , 2013. 'Positive' gentrification, social control and the 'Right to the City' in mixed-income communities: uses and expectations of space and place. International Journal of Urban and Regional Research . 37, 480-502.

Chatterjee, P. , 2013. The Politics of the Governed: Reflections on Popular Politics in Most of the World . Columbia University Press. New York.

Claire, D. , David, G. , Bindi, S. , 2013. Faith and suburbia: secularisation, modernity and the changing geographies of religion in London's suburbs. Transactions of the Institute of British Geographers . 38, 403-419.

Colomb, C. , 2007. Unpacking new labour's 'urban renaissance' agenda: towards a socially sustainable reurbanization of British cities? Planning Practice and Research . 22, 1-24.

Comaroff, J. , Comaroff, J.L. , 2012. Theory from the South: Or, How Euro-America Is Evolving toward Africa . Paradigm Publishers. Boulder, Colorado.

Dwyer, C. , Gilbert, D. , Bindi, S. , 2013, Faith and suburbia: secularisation, modernity and the changing geographies of religion in London's suburbs. Transactions of the British Institute of Geographers . 38, 403-419.

Flusty, S. , 2002. The banality of interdiction: surveillance, control and the displacement of diversity. International Journal of Urban and Regional Research . 25, 658-664.

Fyfe, N. , 2004. Zero tolerance, maximum surveillance? Deviance, difference and crime control in the late modern city, in: Lees, L. (Ed.), The Emancipatory City? Paradoxes and Possibilities . Sage Publications. London, pp. 40-56.

Gotz, G. , Simone, A. , 2003. On belonging and becoming in African cities, in: Tomlinson, R. , Beauregard, R.A. , Bremner, L. , Mangcu, X. (Eds.), Emerging Johannesburg: Perspectives on the Postapartheid City . Routledge. New York, pp. 123-147.

Grosfoguel, R. , 2007. The epistemic decolonial turn. Cultural Studies . 21, 211-223. 
Gutiérrez-Rodríguez, E. , 2010. Migration, Domestic Work and Affect: A Decolonial Approach on Value and the Feminization of Labor . Routledge. New York.

Halbert, L. , Attuyer, K. , 2016. Introduction: the financialisation of urban production: conditions, mediations and transformations. Urban Studies . 53, 1347-1361.

Hall, S.M. , 2015a. Super-diverse street: a 'trans-ethnography' across migrant localities. Ethnic and Racial Studies . 38, 22-37.

Hall, S.M. , 2015b. Migrant urbanisms: ordinary cities and everyday resistance. Sociology . 49, 853-869.

Harvey, D. , 2012. Rebel Cities: From the Right to the City to the Urban Revolution . Verso Books. New York.

Houssay-Holzschuch, M. , 2016. Diss and ditch? What to do with public space, in: De Backer, M. , Melgaço, L. , Varna, G. , Menichelli, F. (Eds.), Order and Conflict in Public Space.

Routledge. London, pp. 216-220.

Jennifer, R. , 2015. 'Arriving at' urban policies: the topological spaces of urban policy mobility. International Journal of Urban and Regional Research . 39, 831-834.

Kihato, C. , 2013. Migrant Women of Johannesburg: Everyday Life in an In-Between City . Palgrave Macmillan. New York.

Landau, L.B. , 2018. Friendship fears and communities of convenience in Africa's urban estuaries: connection as measure of urban condition. Urban Studies . 55, 505-521.

Landau, L.B. , Freemantle, I. , 2010. Tactical cosmopolitanism and idioms of belonging: insertion and self-exclusion in Johannesburg. Journal of Ethnicity and Migration Studies . 36, 375-390.

Lees, L. , Shin, H.B. , López-Morales, E. , 2016. Planetary Gentrification . Polity Press. Cambridge.

Lopez-Morales, E. , 2011. Gentrification by ground-rent dispossession: the shadows cast by large-scale urban renewal in Santiago de Chile. International Journal of Urban and Regional Research . 35, 330-357.

Malcomess, B. , Wilhelm-Solomon, M. , 2016. Valleys of salt in the house of God: religious reterritorialisation and urban space, in: Wilhelm-Solomon, M. , Nunez, L. , Kankonde Bukasa, P. , Malcomess, B. (Eds.), Routes and Rites to the City: Mobility, Diversity and Religious Space in Johannesburg . Palgrave Macmillan. London, pp. 31-60.

Maldonado-Torres, N. , 2007. On the coloniality of being. Cultural Studies . 21, 240-270.

Mbembé, A. , 2003. Necropolitics. Public Culture . 15, 11-40.

Mbembe, A. , 2008. Aesthetics of superfluity, in: Nuttall, S. , Mbembe, A. (Eds.), Johannesburg: The Elusive Metropolis . Duke University Press. Durham, North Carolina, pp. 37-67.

Mbembé, A. , Nuttall, S. , 2004. Writing the world from an African metropolis. Public Culture. 16, 347-372.

Mbembe, A. , Nuttall, S. , 2008. Introduction: Afropolis, in: Nuttall, S. , Mbembe, A. (Eds.), Johannesburg: The Elusive Metropolis . Duke University Press. Durham, North Carolina, pp. 1-33.

McFarlane, C. , 2006. Crossing borders: development, learning and the North-South divide. Third World Quarterly . 27, 1413-1437.

Merrifield, A. , 2013. The Politics of the Encounter: Urban Theory and Protest under Planetary Urbanization . University of Georgia Press. Athens.

Mitchell, D. , 1995. The end of public space? People's park, definitions of the public, and democracy. Annals of the Association of American Geographers . 85, 108-133.

Mouffe, C. , 2005. Which kind of public space for a democratic habitus? in: Hillier, J. , Rooksby, E. (Eds.), Habitus: A Sense of Place . Ashgate Publishing. Farnham, pp. 109-116.

Myers, G.A. , 2011. African Cities: Alternative Visions of Urban Theory and Practice . Zed Books. London.

Németh, J. , 2006. Conflict, exclusion, relocation: skateboarding and public space. Journal of Urban Design . 11, 297-318.

Nuttall, S. , 2004. City forms and writing the 'now' in South Africa. Journal of Southern African Studies . 30, 731-748.

Parker, A. , 2017. The spatial stereotype: the representation and reception of urban films in Johannesburg. Urban Studies. OnlineFirst.

Parnell, S. , Robinson, J. , 2012. (Re)theorizing cities from the Global South: looking beyond neoliberalism. Urban Geography . 33, 593-617. 
Peck, J. , 2015. Cities beyond compare? Regional Studies . 49, 160-182.

Pieterse, E. , 2011. Grasping the unknowable: coming to grips with African urbanisms. Social Dynamics . 37, 5-23.

Robinson, J. , 2003. Postcolonialising geography: tactics and pitfalls. Singapore Journal of Tropical Geography . 24, 273-289.

Robinson, J. , 2006. Ordinary Cities: Between Modernity and Development . Routledge. London.

Robinson, J. , 2011. Cities in a world of cities: the comparative gesture. International Journal of Urban and Regional Research . 35, 1-23.

Robinson, J. 2015. 'Arriving at' urban policies: the topological spaces of urban policy mobility. International Journal of Urban and Regional Research . 39, 831-834.

Roy, A. , 2009. The 21st-century metropolis: new geographies of theory. Regional Studies . 43, 819-830.

Simone, A. , 2001. Straddling the divides: remaking associational life in the informal African city. International Journal of Urban and Regional Research . 25, 102-117.

Simone, A. , 2004. For the City yet to Come: Changing African Life in Four Cities . Duke University Press. Durham, North Carolina.

Simone, A. , 2010. A town on its knees? Economic experimentations with postcolonial urban politics in Africa and Southeast Asia. Theory, Culture and Society . 27, 130-154.

Smith, N. , 2002. New globalism, new urbanism: gentrification as global urban strategy. Antipode. 34, 427-450.

Spivak, G. , 1999. A Critique of of Postcolonial Reason . Harvard University Press. Cambridge, Massachusetts.

Watson, V. , 2014. The case for a Southern perspective in planning theory. International Journal of E-Planning and Research . 3, 23-37.

Winkler, T. , 2013. Why won't downtown Johannesburg 'regenerate'? Reassessing Hillbrow as a case example. Urban Forum . 24, 309-324.

Wood, A. , 2014. The politics of policy circulation: unpacking the relationship between South African and South American cities in the adoption of Bus Rapid Transit. Antipode . 47, 1062-1079.

Zheng, J. , 2013. Creating urban images through global flows: Hong Kong real estate developers in Shanghai's urban redevelopment. City, Culture, Society . 4, 65-76. 